148/4, 381-400., Budapest, 2018

DOI: 10.23928/foldt.kozl.2018.148.4.381

\title{
Stronciumizotóp-sztratigráfia és alkalmazásai
}

\author{
KovÁcs Emma Blanka ${ }^{1}$, KovÁCs Zsófia ${ }^{2,3}$, PÁLFY József ${ }^{1,4}$ \\ Eötvös Loránd Tudományegyetem, Általános és Alkalmazott Földtani Tanszék, 1117 Budapest, Pázmány Péter sétány 1/c \\ (kovacsemmablanka@gmail.com) \\ ${ }^{2}$ Institut für Erdwissenschaften, Karl-Franzens-Universität Graz, 8010 Graz, Heinrichstraße 26, Ausztria (zsofia.kovacs@uni-graz.at) \\ ${ }^{3}$ MTA ATOMKI, Izotóp Klimatológiai és Környezetkutató Központ, 4026 Debrecen, Bem tér 18/c \\ ${ }^{4}$ MTA-MTM-ELTE Paleontológiai Kutatócsoport, 1117 Budapest, Pázmány Péter sétány 1/c (palfy @elte.hu)
}

\section{Strontium isotope stratigraphy and its applications}

Abstract

The late $20^{\text {th }}$ century revival of stratigraphic methods resulted in a burst of chemostratigraphic techniques and their applications, including the rise of strontium isotope stratigraphy. This method utilizes the measured ratio of radiogenic ${ }^{87} \mathrm{Sr}$ and non-radiogenic ${ }^{86} \mathrm{Sr}$ isotopes in samples from sedimentary stratigraphic sections. The residence time of marine $\mathrm{Sr}$, in excess of one million years, is three orders of magnitude longer than the mixing time of the world ocean, resulting in homogenous $\mathrm{Sr}$ isotopic composition of seawater that is recorded by marine carbonate phases precipitated in isotopic equilibrium, biogenic low-Mg calcite being the most faithful among them. The marine $\mathrm{Sr}$ isotopic ratio has been changing continuously in both directions throughout the Earth history, controlled by the ratio of fluxes of ${ }^{87} \mathrm{Sr}$, derived mainly from weathering of continental crustal rocks and delivered to the ocean by riverine influx, and ${ }^{86} \mathrm{Sr}$, from juvenile mantle-derived material primarily from volcanic and hydrothermal activity along mid-oceanic ridges. An increasingly reliable, high-resolution reference curve has been constructed form the Neoproterozoic and the entire Phanerozoic, using independently (mostly biostratigraphically) dated samples. Dating of new samples of only broadly constrained age yields the best results, with better than 1 m.y. precision, in steep intervals of the reference curve, i.e. for times of high rate of change in ${ }^{87} \mathrm{Sr} /{ }^{86} \mathrm{Sr}$. Here we briefly review the theoretical and historical background of the method, the practical issues of sample selection and analytical techniques, and provide case studies from some areas of successful use of Sr isotope stratigraphy. Examples include the Toarcian Jenkyns event, the end-Cretaceous event, and glacial periods in Earth history, when beside their significance for stratigraphic correlation, $\mathrm{Sr}$ isotopes provide clues to the causation of major events in Earth history. Sr isotope stratigraphy has been effectively used to solve correlation problems of shallow marine carbonate platforms, where available biostratigraphies are commonly of low-resolution and fraught with problems of global correlation with pelagic zonation schemes. The method is capable to tackle local and regional correlation problems, including issues of global correlation of sedimentary sequences of the Paratethys. Although this inland sea was characterised by partly endemic faunas, the increasing body of available ${ }^{87} \mathrm{Sr} /{ }^{86} \mathrm{Sr}$ data, as compiled here, provides fresh insight into its stratigraphic and palaeoceanographic evolution. This review intends to pave the way of incorporating $\mathrm{Sr}$ isotope results into regional stratigraphic syntheses and to promote further use of this method in Hungary.

Keywords: chemostratigraphy, stratigraphic methods, age dating, events in Earth history, Paratethys

Összefoglalás

A rétegtan tudományágának módszertani megújulása a 20. század utolsó évtizedeiben magával hozta a kemosztratigráfiai módszerek rohamos fejlődését és alkalmazásuk elterjedését. Ezek egyike a stronciumizotóp-sztratigráfia, ami üledékes rétegsorokban a radiogén ${ }^{87} \mathrm{Sr}$ és a nem radiogén ${ }^{86} \mathrm{Sr}$ izotópok arányának mérésén alapul. A Sr millió éves nagyságrendú óceáni tartózkodási ideje a világtenger ezer éves nagyságrendû keveredési idejéhez képest adott időben homogén tengeri izotóparányhoz vezet, amit a tengervízzel egyensúlyban kiváló karbonátfázisok rögzítenek, legmegbízhatóbban a biogén alacsony Mg-tartalmú kalcit. A rétegtani alkalmazhatóságot az teszi lehetővé, hogy a Sr tengeri izotóparánya a földtörténet során mindenkor változott, a döntően kontinentális kéreg mállásából származó és folyóvízi beszállítás révén a tengerbe jutó ${ }^{87} \mathrm{Sr}$, és a köpenyeredetú, fő́ként az óceánközépi hátsági vulkanizmusból származó ${ }^{86} \mathrm{Sr}$ fluxusának arányától függően. Más független módon, főként biosztratigráfiai úton ismert korú mintákból egyre pontosabb referenciagörbe áll rendelkezésre a neoproterozoikumtól a teljes fanerozoikumra, aminek használatával különösen a görbe meredek szakaszain, azaz időben gyorsan változó Sr izotóparánnyal jellemzett intervallumokban millió év körüli vagy annál is jobb felbontás érhetố el csak közelítôen ismert korú minták kormeghatározásában. A szemle röviden ismerteti a módszer elméleti és történeti hátterét, a mintázás és a mérés gyakorlati kérdéseit, és esettanulmányokon keresztül mutatja be alkalmazásának néhány területét. Példáink között szerepel a toarci Jenkyns-esemény, a kréta végi esemény, és eljegesedési időszakok Sr izotóp-sztratigráfiája, 
ahol a rétegtani korrelációnál is nagyobb jelentőségú a földtörténeti folyamatok ok-okozati összefüggéseinek megértéséhez adott segítség. A módszer korrelációs potenciálját leghatékonyabban sekélytengeri platformok korolásánál lehet kihasználni, ahol a rendelkezésre álló biosztratigráfia felbontása korlátozott és a párhuzamosítás a nyílttengeri rétegsorokkal vitatott. A módszert az elmúlt években dinamikusan növekvő mérési adatbázis alkalmassá teheti regionális rétegtani problémák megoldására, mint például a részben endemikus faunái miatt globális korrelációs kérdéseket felvetô Paratethys rétegsorok kormeghatározására. Szemlénk segíteni kívánja az új eredmények befogadását és ösztönözheti a módszer további magyarországi meghonosodását.

Kulcsszavak: kemosztratigráfia, rétegtani módszerek, kormeghatározás, földtörténeti események, Paratethys

\section{Bevezetés}

A rétegtan tudományága a geológia egyik alappillére. Hagyományos, nagy múltú diszciplína, amelyre sokan úgy tekintenek, mint ami túljutott fénykorán, betöltötte szerepét, már nem fejlődik olyan mértékben, mint a geológia számos más, a közelmúltban divatossá vált területe. Ennek elegáns cáfolatát adja MiALL (2013), bemutatva a 21. századi „,Szofisztikált sztratigráfiát”, ami új módszerek arzenálját felvonultatva célozza meg a korábbinál nagyobb időbeli felbontás, pontosabb és megbízhatóbb korreláció, illetve ezek számszerúsítésének elérését.

Az elmúlt évtizedekben kifejlesztett modern, kifinomult módszerek egyike a Sr izotóp-sztratigráfia (vagy bevett angol rövidítésével SIS). A kemosztratigráfiai módszerek családjába tartozik, az üledékes képződmények időben változó geokémiai sajátosságainak egyikét, a Sr izotópjainak arányát alkalmazza rétegtani célra. Kihasználja, hogy a tengervízbe a radiogén ${ }^{87}$ Sr izotóp elsôsorban a kontinentális kéreg mállása révén kerül, míg a nem radiogén ${ }^{86} \mathrm{Sr}$ főleg juvenilis, köpenyeredetû, az óceáni kéregképződéshez kapcsolódó tenger alatti vulkanizmusból származik. A két folyamat arányának eltolódása a ${ }^{87} \mathrm{Sr} /{ }^{86} \mathrm{Sr}$ izotóparány változásához vezet, ami megőrződik a mindenkori tengervízzel egyensúlyban kivált ásványfázisokban, pl. közönséges karbonátban is.

A mára már érettnek tekinthetô módszerről fejlődése során több összefoglaló cikk jelent meg (pl. MCARTHUR 1994; VEIZER et al. 1997). Az egyik legátfogóbb tanulmány (MCARTHUR et al. 2012) a geológiai időskála fejlesztésében és kalibrálásában betöltött szerepe okán kapott helyet az időskála mértékadó referencia kézikönyvében (GRADSTEIN et al. 2012). A Sr izotóparány időbeli változásai nem csak a rétegtani gyakorlatban alkalmazhatóak, hanem fontos földtörténeti információt hordoznak: a Föld rendszerszintû múködésébe engednek bepillantást a szárazföldi mállás intenzitása és óceánközépi hátságok aktivitása arányának változásait rögzítve. Tágabb értelemben ezek az éghajlat alakulásának és a lemeztektonikai folyamatok sebességének az egyensúlyi helyzetét vagy annak mindenkori eltolódását tükrözik.

A SIS hazai bevezetésére a közelmúltban tettek először nagyobb kutatási projekt keretében lépéseket LESS György és munkatársai, az eredményeik publikálása folyamatban van (PARENTE et al. 2013; Less \& FrIJIA 2015; Less et al. 2015a, b,). Magyar nyelvú áttekintő irodalma a témának még nincs, korábban említésre sem került a széles körben használatos rétegtani módszerek között (CSÁSZÁR 1998, HAAs et al. 2008). A jelen szemle célja a SIS módszerének, történetének, elméleti hátterének és gyakorlati alkalmazásának bemutatása, erôsségeinek és korlátainak a nemzetközi irodalomból vett példákon keresztüli szemléltetésével.

\section{A stronciumizotóp-sztratigráfia (SIS) történeti áttekintése}

Az ötletet, hogy a ${ }^{87} \mathrm{Sr} /{ }^{86} \mathrm{Sr}$ aránynak sztratigráfiai jelentősége is lehet, először WICKMAN (1948) vetette fel. Szerinte $\mathrm{a}^{87} \mathrm{Sr} /{ }^{86} \mathrm{Sr}$ aránynak az idő előrehaladtával nőnie kell a ${ }^{87} \mathrm{Rb}$ bomlásával keletkező radiogén ${ }^{87} \mathrm{Sr}$ növekvő mennyisége miatt. Ezzel ellentétben PETERMAN et al. (1970) fanerozoikumi fosszíliákon kimutatták, hogy a ${ }^{87} \mathrm{Sr} /{ }^{86} \mathrm{Sr}$ arány többször változott mindkét irányban, a földtörténet során több csúcs is kimutatható. Ezen kívül bebizonyították, hogy a mai tengerek vizének összetétele stronciumra nézve egységes. A SIS módszerének modern alapjait BURKE et al. (1982) fektették le, egyúttal megalkották a felső-kambriumtól a holocénig az elsô átfogó fanerozoikumi Sr-izotóp görbét (1. ábra). Az azóta eltelt évtizedekben a módszer alkalmazása egyre inkább tért hódított.

\section{A stroncium körforgása a természetben}

A Sr körforgását a természetben a 2. ábra szemlélteti. A köpenyből magmás tevékenység útján kerülhet $\mathrm{Sr}$ a kontinentális és az óceáni kéregbe. A Rb a Sr-nál inkompatibilisebb elem, így a ${ }^{87} \mathrm{Rb}$ jobban dúsul a kontinentális kéregben, mint az óceániban. Ebből a radioaktív izotópból $\beta^{-}$ bomlással ${ }^{87} \mathrm{Sr}$ keletkezik. A kontinentális kéreg Sr-tartalma szárazföldi mállás révén a folyókba, és azokon keresztül az óceánokba kerül. Az óceáni kéregből a bazalt hidrotermális átalakulásával jut a köpenyeredetű ${ }^{86} \mathrm{Sr}$ az óceánba. Az óceánok mindenkori Sr izotóparányát az üledékes rétegsorok őrizhetik meg. A Sr-tartalmú kőzetek egyrészt az orogén övekben felszínre kerülhetnek, ahol ismét ki vannak téve mállásnak, másrészt a litoszféra szubdukciójával a köpenybe juthatnak.

\section{Az óceánok homogenitása}

A mai világóceánban a Sr tartózkodási ideje $\left(\sim 1-4 \times 10^{6}\right.$ év; EldERFIELD 1986, SAWAKI et al. 2010, MCARTHUR et al. 2012) nagyságrendekkel hosszabb, mint a tenger vizének keveredési ideje ( 10³ év; RICHTER \& TUREKIAN 1993), így kijelenthető, hogy Sr-ra nézve a tengervíz mindig jól kevert, 


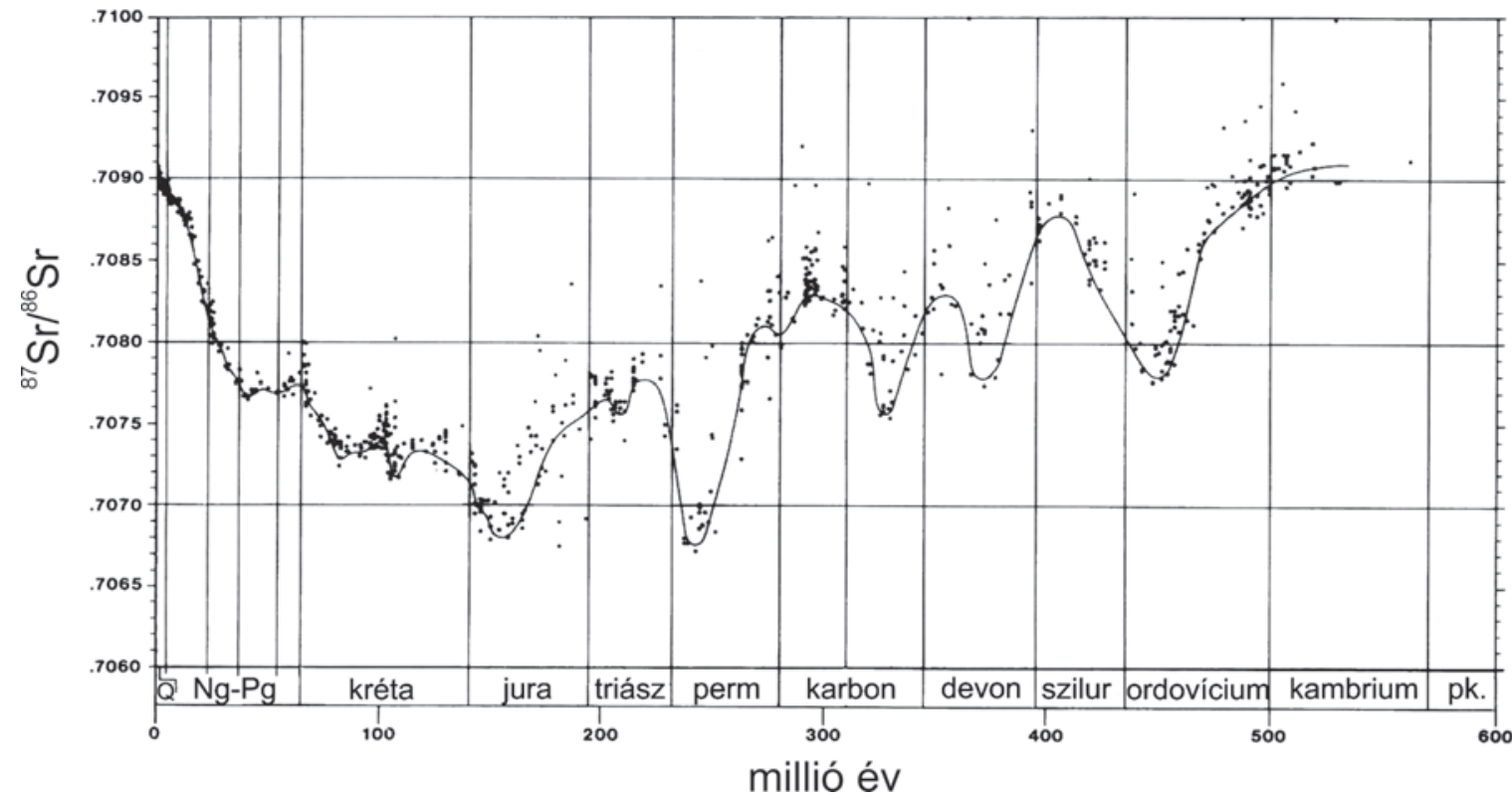

1. ábra. A tengeri ${ }^{87} \mathrm{Sr} /{ }^{86} \mathrm{Sr}$ izotóparány időbeli változásának első referenciagörbéje a fanerozoikumra (BuRKE et al. 1982)

Figure 1. The first Phanerozoic reference curve of secular changes in marine ${ }^{87} \mathrm{Sr} /{ }^{86} \mathrm{Sr}$ isotope ratio (after BURKE et al. 1982)

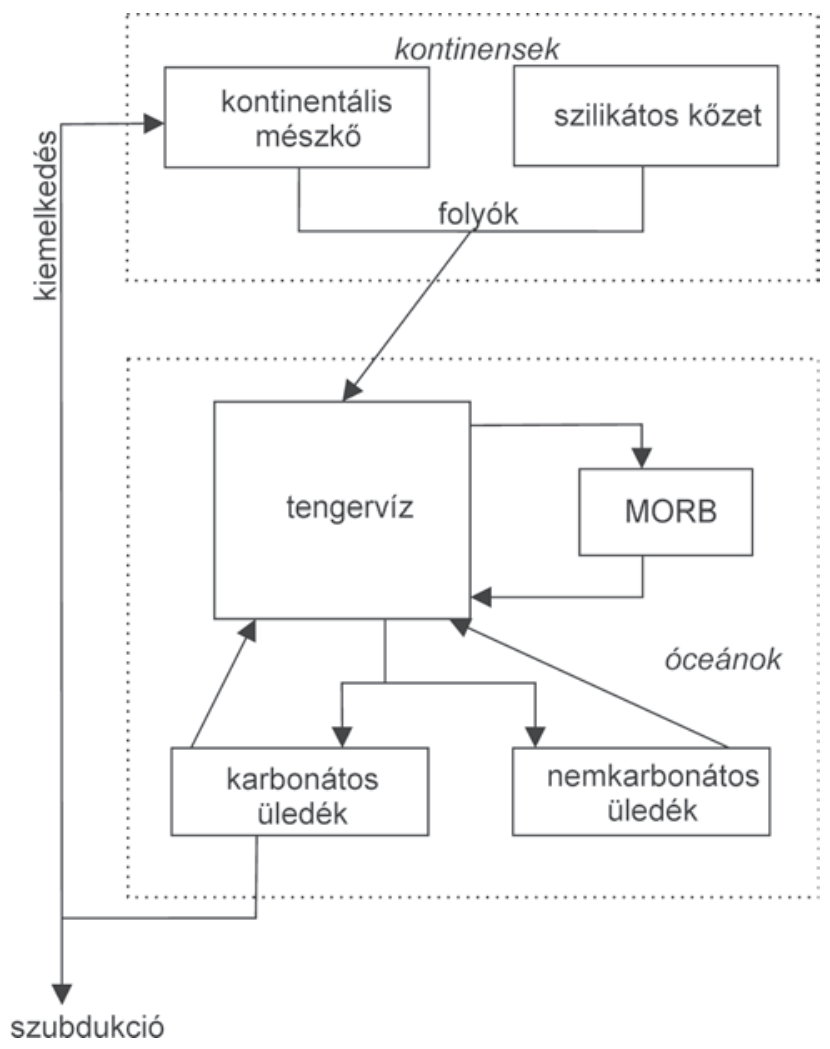

2. ábra. A Sr körforgása a természetben (PALMER \& ELDERFIELD 1985 alapján) Figure 2. The natural Sr cycle (after PALMER \& ELDERFIELD1985)

ebből következően a ${ }^{87} \mathrm{Sr} /{ }^{86} \mathrm{Sr}$ arány adott időben mindenütt azonos. Ezt recens mészvázak vizsgálatával is alátámasztották (DEPAOLO \& INGRAM 1985). A SIS használhatósága annak feltételezésén alapul, hogy az óceánban a múltban is homogén volt a stroncium eloszlása. Bár ez közvetlenül nem bizonyítható, de helytállósága általánosan elfogadott (McArThur et al. 1994). A Sr koncentrációja kis mértékben változik az egyes óceánokban a mélység, illetve a sótartalom függvényében (BRASS \& TUREKIAN 1974), de 50 m alatt már egységes, 7,6士0,1 ppm átlagos értékkel (BERNAT et al. 1972).

\section{Szárazföldekról felszíni vizekkel történó beszállítás}

A tengervízben oldott Sr legfőbb forrása a folyóvizek által szállított Sr (PALMER \& ELDERFIELD 1985). BRASS (1976) szerint a tengerbe érkező ${ }^{87} \mathrm{Sr} /{ }^{86} \mathrm{Sr}$ arányát alapvetően a mállásnak kitett alábbi három különféle forrásterületről való beszállítódás aránya határozza meg: (1) idős szialikus kristályos kőzetek, (2) bázikus és neutrális magmás kőzetek, valamint az orogén övek fiatal magmás kőzetei és (3) a felszínre került mészkő. A kontinentális mállás mértékét klimatikus és földrajzi tényezők határozzák meg (PALMER \& ELDERFIELD 1985).

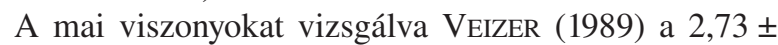
$0,09 \times 10^{12} \mathrm{~g} / \mathrm{e} v$ globális folyóvízi beszállításhoz súlyozott átlag számítása alapján $0,7101 \pm 0,0005{ }^{87} \mathrm{Sr} /{ }^{86} \mathrm{Sr}$ izotóparányt rendelt. PEARCE et al. (2015) újabb vizsgálatai szerint a folyóvízi ${ }^{87} \mathrm{Sr} /{ }^{86} \mathrm{Sr}$ arány 0,70438-0,73723 között változik, a súlyozott átlagértéke 0,71299 .

\section{Szárazföldekröl \\ felszín alatti vizekkel történó beszállítás}

A felszín alatti vizek közvetlenül is bejutnak az óceánokba. Noha ez csak az össz felszíni lefolyás 5\%-át teszi ki, hatása az esetleges nagyobb Sr-tartalom miatt jelentős lehet. Becslések szerint $1,95 \pm 0,5 \times 10^{12} \mathrm{~g} / \mathrm{e} v \mathrm{Sr}$ áramlik az 
óceánokba felszín alatti vizekből, a felszíni vizekkel megegyező $0,7101 \pm 0,0005{ }^{87} \mathrm{Sr} /{ }^{86} \mathrm{Sr}$ aránnyal (VeIzer 1989). Azonban ez a legnehezebben lehatárolható és meghatározható változó a Sr-rendszerben.

\section{Az óceáni kéreg és a tengervíz kölcsönhatása}

Az óceáni bazaltos kéreg és a tengervíz Sr-tartalma közötti kapcsolat az óceánközépi hátságoknál jelenlevő hidrotermális rendszeren keresztül valósul meg (ELDERFIELD \& GREAVEs 1981), ami a tengervíz izotópos összetételére jelentôs hatással bír (PALMER \& ELDERFIELD 1985). Az óceánközépi hátságoknál az óceáni kérget keresztülszelő hidrotermális rendszeren 1,3-9 $\times 10^{17} \mathrm{~g}$ tengervíz áramlik át évente (WOLERY \& SLEeP 1976), és a $~ 6,5 \mathrm{~km}$ vastag óceáni kéreg felsô 4-5 km-ét metaszomatizálja (SPOONER et al. 1974). Pearce et al. (2015) vizsgálatai szerint a hidrotermális fluidum ${ }^{87} \mathrm{Sr} /{ }^{86} \mathrm{Sr}$ aránya $0,70362-0,70916$ között mozog.

\section{Diagenetikus eredetú betáplálás}

Az óceánaljzatra lerakódó mésziszapban a karbonátásványok diagenetikus átkristályosodása során $\mathrm{Sr}$ szabadul fel és a pórusvízen keresztül diffúzió és/vagy advekció révén visszajut a tengervízbe (VEIzER 1989). A mélytengeri üledékekből származó diagenetikus eredetú Sr-betáplálás $\sim 0,26 \times 10^{12} \mathrm{~g} / \mathrm{e} v$, melynek ${ }^{87} \mathrm{Sr} /{ }^{86} \mathrm{Sr}$ aránya $\sim 0,7087$ (PALMer \& Elderfield 1985). Richter \& LiANG (1993) szerint a diagenetikus eredetú betáplálás elérheti a szárazföldi beszállítódás 15\%-át. A PEARCE et al. (2015) által vizsgált pórusvizekben a ${ }^{87} \mathrm{Sr} /{ }^{86} \mathrm{Sr}$ arány $0,70916-$ 0,70918 között váltakozott.

A pórusvíz Sr-izotópos összetételét az alábbiak jelenléte befolyásolhatja (ELDERFIELD \& GIESKES 1982): (1) terrigén törmelék $\left({ }^{87} \mathrm{Sr} /{ }^{86} \mathrm{Sr} \sim 0,716\right)$, (2) biogén karbonátok $\left({ }^{87} \mathrm{Sr} /{ }^{86} \mathrm{Sr}\right.$ = 0,7092-0,7075 az elmúlt 100 millió évben), (3) vulkanitok, általában bazalt, vulkáni hamu és üveg $\left({ }^{87} \mathrm{Sr} /{ }^{86} \mathrm{Sr}=\right.$ 0,7027-0,705, a kor és átalakultság függvényében). Ezek közül az (1) tényező hatása jelentéktelen, míg a (3) tényező domináns.

\section{A SIS során alkalmazott vizsgálati módszerek}

\section{A minták kiválasztása}

A SIS módszere csak tengeri üledékes környezetből származó mintákon alkalmazható, de ezen belül sikeresnek bizonyult karbonáton, evaporiton, bariton, foszfáton és ősmaradványok vázelemein is. A felhasználható anyagok változatossága abból is következik, hogy a Sr-izotópok, ellentétben például a szén izotópjaival, nem frakcionálódnak biológiai vagy kémiai folyamatok során (MILLER et al. 1993).
Peterman et al. (1970) elsődleges $\mathrm{CaCO}_{3}$ vázat kiválasztó makrofosszíliákon mutatták ki először a Sr izotóparány változásait. Később DASCH \& BISCAYE (1971) bebizonyították, hogy ugyanez kimutatható foraminiferákon is, melyek szélesebb körben fordulnak eló.

A tengeri ${ }^{87} \mathrm{Sr} /{ }^{86} \mathrm{Sr}$ arány változását először leíró görbe megalkotásánál BURKE et al. (1982) kizárták további elemzésből a nem tengeri és a nagy mértékben átalakult tengeri mintákat. A kainozoikumból mélytengeri DSDP fúrómagokat, míg a mezozoikumból és a paleozoikumból $\geq 200$ ppm Sr-tartalmú és $\leq 10 \%$ oldhatatlan komponenst tartalmazó mintákat használtak.

A paleozoikumban a referenciagörbe adatpontjait adó mérésekhez a brachiopodák a legalkalmasabbak (PopP et al. 1986), mint gyakori, környezet- és korjelző jelentőséggel is bíró ôsmaradványok, melyek a diagenetikus átalakulással szemben ellenálló, alacsony Mg-tartalmú kalcitvázukat izotópegyensúly mellett választják ki. Az esetleges diagenetikus átalakulást sorozatcsiszolatok készítésével könnyú felismerni, mivel belső szerkezetük jól ismert. JONES et al. (1994a) a kora-jura referenciagörbe megalkotásához belemniteszeket és Ostrea-féle kagylók vázanyagát is vizsgálta, mivel ezek is alacsony Mg-tartalmú kalcitvázzal rendelkeznek, és szintén kiválóan megórizhetik az eredeti, tengeri ${ }^{87} \mathrm{Sr} /{ }^{86} \mathrm{Sr}$ arányt.

A diagenezis során a metastabil aragonit jelentős mértékben átkristályosodhat, míg a alacsony Mg-tartalmú kalcit (angol rövidítéssel LMC) kevésbé. Ebből következik, hogy ahol eredeti aragonitvázú ôsmaradványok találhatóak, ott az azokkal együtt talált LMC-vázúak nem szenvedhettek jelentôs mértékú változást a lerakódás óta (BRAND 1987). Fontos tehát ellenőrizni a Sr izotóparány mérése előtt, hogy feltételezhetóen az eredeti tengervíz izotóp-összetételét tükrözi-e az eredmény. A diagenetikus átalakuláson átesett mintákat több módszerrel is ki lehet szúrni, azonban a megbízható eredmény érdekében az alább felsorolt módszerek közül mindig ajánlatos több együttes alkalmazása. A körültekintô eljárás szükségességének hangsúlyozása mellett fontos megjegyezni, hogy a ${ }^{87} \mathrm{Sr} /{ }^{86} \mathrm{Sr}$ arány, hasonlóan a $\delta^{13} \mathrm{C}$-hez, sokkal nehezebben íródik felül, mint például a $\delta^{18} \mathrm{O}$. Kis víz:kózet aránynál, illetve ha a feloldódó karbonátok pufferhatást fejtenek ki, az eredeti Sr izotóparány jó eséllyel megốrződik (BANNER et al. 1990, VeIZER et al. 1999).

\section{Elözetes vizsgálatok a minták szúrésére}

Az elsőként alkalmazott múszeres vizsgálati módszer leggyakrabban a pásztázó elektronmikroszkóp (SEM) használata, a mészváz mikrostruktúrája esetleges elváltozásának megfigyelésére. Az eredeti héjszerkezet megórződése a minta diagenetikus átalakulásának hiányára utal (MCARTHUR 1994).

A SEM vizsgálatok után általában a porminta ásványos összetételét határozzák meg röntgen-diffrakció (XRD) segítségével. Monomineralikus mintán akár 0,5\%-os kristályos szennyezés (MCARTHUR 1994) is ki- 
mutatható XRD segítségével, ezért az aragonit átalakulásának meghatározásához a legtöbb esetben jól használható ez a technika. Azonban mivel a kalcit gyakran nagyobb kristályszerkezeti változás nélkül is átkristályosodhat, az XRD nem mindig képes a kalcitvázat átalakulásának felismerésére.

\section{Vékonycsiszolatos vizsgálatok és katódlumineszcencia}

Polírozott vékony- és vastag csiszolatokat eredményesen használnak petrográfiai és katódlumineszcens vizsgálatokhoz, mivel ezeken jól láthatóak a mintán belüli szöveti változások (KAUFMAN et al. 1993). Bár elfogadott tény, hogy a lumineszkáló karbonátok általában átkristályosodtak (MCARTHUR 1994), BARBIN et al. (2009) recens biogén karbonátokon kimutatták, hogy azok nem ritkán ásványos összetételüktôl, a létrehozó szervezetek élőhelyétől, életmódjától és környezetétôl függetlenül is lumineszkálnak, vagyis a módszer önmagában nem alkalmas a diagenetikus átalakulás egyértelmú megállapítására.

A diagenetikus karbonátoknak általában nagyobb a Mnés Fe- és alacsonyabb a Sr-tartalmuk, mint az eredetileg lerakódott tengeri karbonátoknak. Katódlumineszcens vizsgálattal könnyen kimutatható a Mn-gazdag másodlagos kalcit a SIS során gyakran vizsgált brachiopoda vázakon (Popp et al. 1986).

\section{Fóelem-analízis}

A minta fóelem-összetétele is utalhat a ${ }^{87} \mathrm{Sr} /{ }^{86} \mathrm{Sr}$ jel eredetiségére, illetve a zavaró detritális komponensek jelenlétére. A minták $\mathrm{Al} / \mathrm{Ca}, \mathrm{Si} / \mathrm{Ca}, \mathrm{K} / \mathrm{Ca}$ arányának és a ${ }^{87} \mathrm{Sr} /{ }^{86} \mathrm{Sr}$ izotóparányának összevetése egyszerú módja az esetleges sziliciklasztos komponensek kimutatásának. Az Al-tartalom jelezheti rétegszilikátok jelenlétét, melyek közül különösen a csillámok módosíthatják az eredeti ${ }^{87} \mathrm{Sr} /{ }^{86} \mathrm{Sr}$ arányt, akár kis koncentráció mellett is. Teljes főelem-elemzéssel olyan rosszul kristályosodott szennyeződések is kimutathatók, melyek röntgen-diffrakcióval nem észlelhetôk (MCARTHUR 1994).

\section{Nyomelem-analízis}

$\mathrm{CaCO}_{3}$ kiválásakor a kristályrácsban a $\mathrm{Ca}^{2+}$-t nyomelemnyi mennyiségben $\mathrm{Sr}^{2+}, \mathrm{Mg}^{2+}, \mathrm{Fe}^{2+}$ és $\mathrm{Mn}^{2+}$ helyettesítheti. A diagenetikus folyamatok általában csökkentik a $\mathrm{Sr}^{2+}$ mennyiségét, míg növelik a másik három kationét (3. $a ́ b r a)$. Különösképpen a $\mathrm{Mn} / \mathrm{Ca}$ és $\mathrm{Fe} / \mathrm{Ca}$ arány alkalmas a diagenetikus átalakulás nyomon követésére (VEIzER \& FRITZ 1976).

MORRISON \& BRAND (1988) vizsgálatai szerint a $\mathrm{Sr} / \mathrm{Ca}$ arány csökkenésével a Mn-tartalom a diagenetikus átalakulás elôrehaladásával nô, hasonlóan a Mg-tartalomhoz. Aragonit esetében a 100 ppm-et meghaladó Mg-tartalom átalakulást jelez. Biogén karbonátokban szub-oxikus, illetve anoxikus körülmények között lezajló diagenetikus válto-

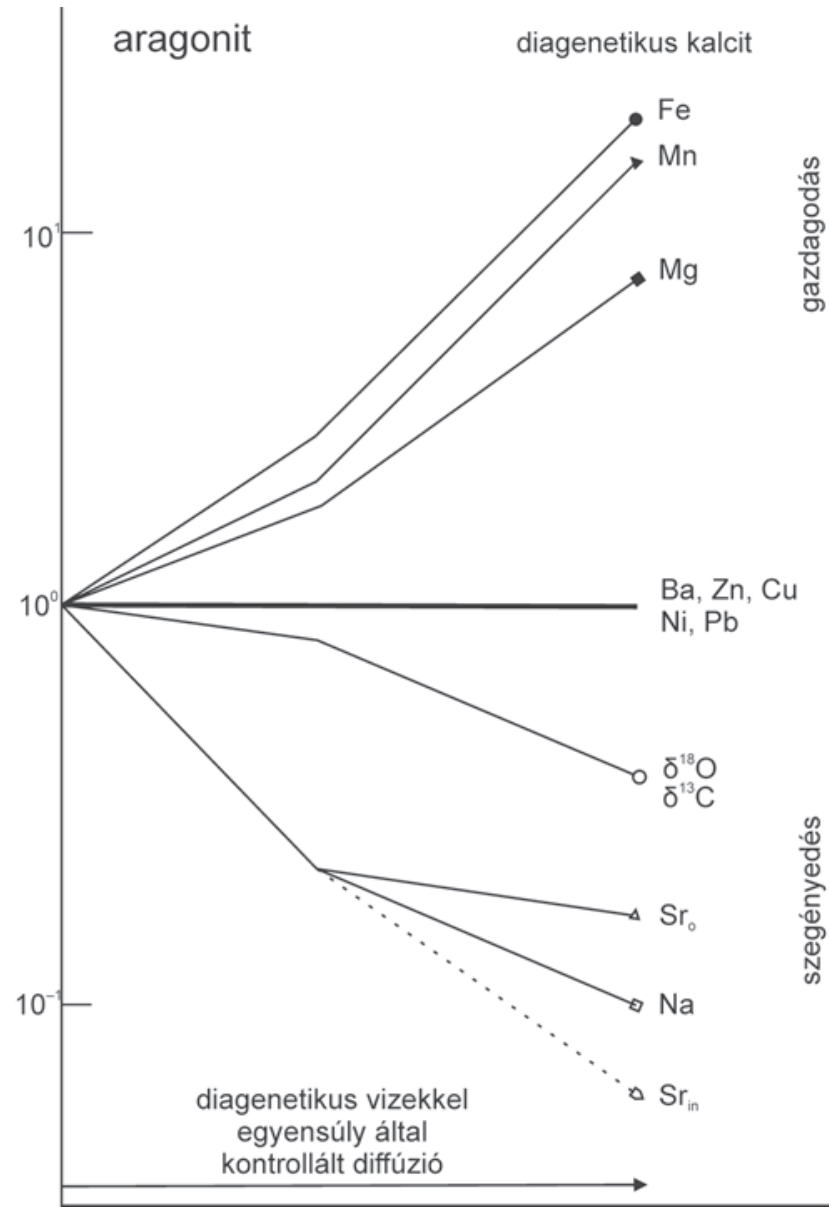

3. ábra. Diagenetikus fluidumok és folyamatok által okozott geokémiai változások aragonit átalakulása során (BRAND 1989b alapján)

Figure 3. Geochemical changes in aragonite induced by diagenetic fluids (after BRAND 1989b)

zást jelezhet a 100 ppm-et meghaladó Fe- és/vagy Mntartalom (MCARTHUR 1994).

A kis Mg-tartalmú belemnitesz rosztrum átalakulását általában a rendszerben jelenlévő másodlagos kalcit jelzi. VeIzer \& Fritz (1976) szerint a vázban és a befoglaló kőzetben levő $\mathrm{Mn}(\mathrm{Fe})$ diagenetikus átalakulást jelzô elemek koncentrációjából kiszámítható az átalakulás mértéke az alábbi egyenlet alapján:

átalakulás mértéke $(\%)=\frac{\mathrm{Mn}(\mathrm{Fe})_{\text {váz }}-\mathrm{Mn}(\mathrm{Fe})_{\text {egyensúlyi konc. }{ }^{*} 100}}{\mathrm{Mn}(\mathrm{Fe})_{\text {befoglaló kôzet karbonátja }}-\mathrm{Mn}(\mathrm{Fe})_{\text {egyensúlyi konc }}}$

\section{Stabilizotóp-összetétel}

Jó megtartás esetén a $\delta^{18} \mathrm{O}$ és a $\delta^{13} \mathrm{C}$ értékek (3. ábra) a tengervíz eredeti izotóp-összetételét és hőmérsékletét tükrözik a kalcit kiválásakor, de ezek más környezeti paraméterektől, pl. a sótartalomtól is függenek (BRAND 1989a). $\mathrm{Az}$ erősebben átalakult ôsmaradvány-vázanyagban nô a $\delta^{16} \mathrm{O}$ - és $\delta^{12} \mathrm{C}$-tartalom, vagyis $\delta^{18} \mathrm{O}$ és $\delta^{13} \mathrm{C}$ értékei csökkennek (BRAND 1989b). 


\section{Az adatok belsó következetessége}

Az utólagos átalakulás felismerésének további módja lehet két különböző, akár különböző anyagú (pl. aragonit és kalcit), de azonos rétegtani szintból származó mintából mért ${ }^{87} \mathrm{Sr} /{ }^{86} \mathrm{Sr}$ arány összehasonlítása. Ennek érdekes példáját adta az Enewetak-atoll vizsgálata. A Marshall-szigeteken található atoll központját alkotó kora-eocén bazaltvulkán ma 1400 m-rel a tengerszint alatt helyezkedik. LUDWIG et al. (1988) azonos mélységben vett kalcit és aragonit minták összehasonlításából kimutatták, hogy mindkét ásványfázis az eredeti ${ }^{87} \mathrm{Sr} /{ }^{86} \mathrm{Sr}$ arányt hordozza.

Ennek ellentmondó eredményekre jutottak MCARTHUR et al. (1990) vizsgálatai. Azonos szintből vett karbonát és foszforit mintákon azt tapasztalták, hogy azok ${ }^{87} \mathrm{Sr} /{ }^{86} \mathrm{Sr}$ aránya különböző. Ennek magyarázata lehet, hogy más korban keletkezett a két ásványfázis, annak ellenére, hogy azonos rétegtani szintből származtak. Ugyanis a karbonát utólagos foszfátosodása során a pórusvízből (sekély betemetődési mélységben ez megfelel a tengervíznek) kiváló frankolit (karbonát-fluorapatit) a pórusvíz Sr izotóp-összetételét örökli meg és nem a karbonátét.

Mivel a diagenetikus felülbélyegzés lehetőségének kiszúrése kiemelkedő fontosságú, egy szintből több jó megtartású minta mérése nagyban növelheti az eredmények megbízhatóságát. Ha a mért értékek hasonlóak, azaz szórásuk kicsi, a SIS kormeghatározása hiteles, míg ellenkező esetben diagenetikus hatásra gyanakodhatunk.

\section{Mintaelókészítés, analitikai módszerek és a mérési eredmények hibaszámítása}

A minták előkészítése során a cél az eredeti ásványok feloldása anélkül, hogy az átkristályosodott fázisok vagy a szenynyezések is belekerülnének az oldatba. Ez szelektív oldásos technikák alkalmazásával érhető el (MCARTHUR 1994).

Első lépésként mikrofúrások segítségével pormintát vesznek, elkerülve a kőzet láthatóan átalakult részeit, valamint az utólag kialakult ereket. Ennek során azonban nagyon finom szemcseméretû sziliciklaszt is gyakran belekerül a pormintába. Ezután a port hígított ecetsavban vagy sósavban tárják fel, hogy a szilikátásványok vagy egyéb nemkívánatos másodlagos elegyrészek, pl. dolomit ne oldódjanak fel. Miután az oldhatatlan elegyrészeket eltávolítják, az oldott mintát bepárolják, majd salétromsavban újraoldják (SAWAKI et al. 2010).

Ezután a Sr-ot különböző molaritású salétromsavval kémiailag szeparálják, múgyantával részlegesen feltöltött oszlopokban. A múgyanta a sav erôsségének függvényében tartja vissza vagy engedi át a különböző elemeket. Ezzel az eljárással a Sr elválasztható a vele együtt előforduló mátrix elemektől ( $\mathrm{K}, \mathrm{Mg}, \mathrm{Ca}, \mathrm{Fe})$ és a Rb-tól. Ez utóbbi elengedhetetlen az egyébként fellépó izobár interferencia miatt. Végül a Sr izotópjainak arányát multikollektoros induktív csatolású plazma tömegspektrométerrel (MC-ICP-MS) vagy termális ionizációs tömegspektrométerrel (TIMS) mérik meg. Az utóbbi módszer előnye, hogy a későbbiekben kevesebb korrekciót kell alkalmazni. Magyarországon korábban nem volt meg a múszeres háttér a Sr izotóparány mérésére, azonban az MTA ATOMKI debreceni laboratóriumában e tanulmány írásakor már a megvalósulás előtt áll az MC-ICP-MS készülék beüzemelése.

Mivel a ${ }^{87} \mathrm{Sr} /{ }^{86} \mathrm{Sr}$ méréseket befolyásolják a mérési körülmények közötti eltérések a különböző laboratóriumokban, minden esetben szükséges az adott mintával párhuzamosan egy referenciaanyag mérése is. Az ismert izotóp-összetételú referenciaanyagra kapott érték alapján számítható a minta mérésekor kapott nyers ${ }^{87} \mathrm{Sr} /{ }^{86} \mathrm{Sr}$ arány szükséges korrekciója. A legtöbb vizsgálatban három referenciaanyag egyikét alkalmazták, közülük a leggyakrabban használt a NIST-987 (National Institute of Standards and Technology 987, korábbi nevén SRM-987) szintetikus $\mathrm{SrCO}_{3}$, melynek ${ }^{87} \mathrm{Sr} /{ }^{86} \mathrm{Sr}$ izotóparánya 0,710248 . Az EN-1 referenciaanyag az Enewetak-atollról származó recens Tridacna kagyló, a karbonátján mért ${ }^{87} \mathrm{Sr} /{ }^{86} \mathrm{Sr}$ arány 0,709174 . Korábban előfordult az E\&A (Eimer és Amend) referenciaanyag alkalmazása is, a $0,708022 \pm 4$ értékkel bíró $\mathrm{SrCO}_{3}$ azonban ma már nem használatos (MCARTHUR et al. 2012).

A mérési eredmény minőségét fejezi ki a belső pontosság (internal precision/within-run precision). Ezt az izotóparány vizsgálatánál a következőképpen adják meg:

$$
\text { I.P. }=2 * \text { se }=\frac{2 * \mathrm{sd}}{\sqrt{\mathrm{N}}}
$$

ahol se az átlag standard hibája, $s d$ a mérések standard eltérése (más néven standard deviációja vagy szórása) és $N$ a mérések száma. Ideális esetben 95\%-os valószínúséggel megismételhető az analízis $\pm 2 s e$-n belül, így gyakran ezt az értéket közlik hibaértékként az izotóparányok meghatározásánál (THIRLWALL 1991).

A külső pontosságot (external precision/ reproducibility) általában a tömegspektrométerrel mért izotóparányoknak a referenciaértéktől való eltéréséből számolják. 95\%-os valószínúséggel a referenciaérték is $2 s d$ távolságon belül esik a mérési eredmények átlagától. Ebből számítható a megismételhetőség (azonos minta újravizsgálása) és a reprodukálhatóság (laboratóriumok közötti összehasonlíthatóság). $\mathrm{A}^{87} \mathrm{Sr} /{ }^{86} \mathrm{Sr}$ arányra publikált reprodukálhatósági értékek változóak, a standardokon alapulva $\pm 0,000020$ \pm 0,000070 (2 sd) közöttiek (THIRLWALL 1991).

A mérési eredményt es annak bizonytalanságát a mérések átlagával és az azokból képzett $2 s d$ értékkel adják meg a leggyakrabban. 2 sd esetén $~ 95 \%$ biztosak lehetünk hogy az egyes mérések az átlag körüli $2 s d$ intervallumba esnek (MCARTHur 1994). Ugyanezt a statisztikát a referenciaanyagra is kiszámítják. Egy minta bizonytalansága nem lehet kisebb mint az összes referenciamérés átlaga körül képzett 2 standard deviáció.

\section{Korrekciók}

Az adatok közlése előtt többféle korrekció szükséges, melyeket a modern tömegspektrométerekhez kapcsolt 
szoftver automatikusan elvégez. A legfontosabb ezek közül a rubídium és a kripton korrekció, valamint a múszerre jellemző izotópfrakcionáció korrekciója. Ezek közül a Rb és a Kr korrekciója csak MC-ICP-MS mérésnél indokolt.

Mivel a ${ }^{87} \mathrm{Rb}$ természetes úton az idô elórehaladtával folyamatosan bomlik, az ebből keletkező ${ }^{87} \mathrm{Sr}$ az egyébként tökéletesen megőrződött mintán mért ${ }^{87} \mathrm{Sr} /{ }^{86} \mathrm{Sr}$ arányt pozitív irányba eltolja. Ökölszabályként kimondható, hogy 0,1 ppm-nél magasabb Rb-koncentráció esetén, vagy 50 millió évnél idősebb minta esetén Rb-korrekciót kell alkalmazni (MCARTHUR et al. 2012).

Kripton korrekcióra az argon vivőgáz használata miatt van szükség, mellyel a vizsgálandó anyagot juttatjuk a tömegspektrométerbe. Ez kis mennyiségben mindig tartalmaz kriptont is, a ${ }^{86} \mathrm{Kr}^{+}$a ${ }^{86} \mathrm{Sr}-\mathrm{mal},{ }^{84} \mathrm{Kr}^{+}$pedig a ${ }^{84} \mathrm{Sr}-\mathrm{mal}$ interferál (GARCÍA-RUIZ et al. 2008).

A múszerre jellemző izotópfrakcionáció korrekciója más-más okból ugyan, de mindkét múszer használatakor szükséges. TIMS esetében a minta bejuttatása a spektrométerbe evaporációval történik, melynek során a gáz fázis a könnyebb ionokban dúsul. Ezzel ellen-tétben MC-ICP-MS-nél a kationok egymást taszító viselkedése nyomán a plazma centrumában domináló nehezebb ionok lépnek be nagyobb arányban a spektrométerbe.

A múszeres analitika fejlődése révén és a fent leírt minőségellenôrzési, mintaelő́készítési, mérési és adatfeldolgozási protokollt használva ma már rutinszerúen érhető el olyan pontosság, hogy $\mathrm{a}^{87} \mathrm{Sr} /{ }^{86} \mathrm{Sr}$ arány hat értékes tizedes jegyre meghatározható.
VeIZER \& COMPSTON (1974) kezdeti lépései után az első fanerozoikumi referenciagörbét BURKE et al. (1982) alkották meg, 786 adatpont segítségével (1. ábra). A Sr izotóparány változásainak mind részletesebb megismerése a földtörténet egyes szakaszaiban azóta is folyik (pl. VeIzer et al. 1983; Miller et al. 1988; HODELL et al. 1989; KÜRSCHNER et al. 1993; DenISON et al. 1994; INGRAM et al. 1994; Jones et al. 1994a, b; MCARTHUR et al. 1994; BRUCKSCHEN et al. 1995; Vonhof \& SMit 1997; Denison et al. 1998; AzMy et al. 1999; BRUCKSCHEN et al. 1999; KORTE et al. 2003; SAWAKI et al. 2010; Price et al. 2016; RUHL et al. 2016; Dudás et al. 2017). A referenciagörbe bevezetése utáni első nagy összefoglaló munka Veizer et al. (1999) érdeme. A ma széles

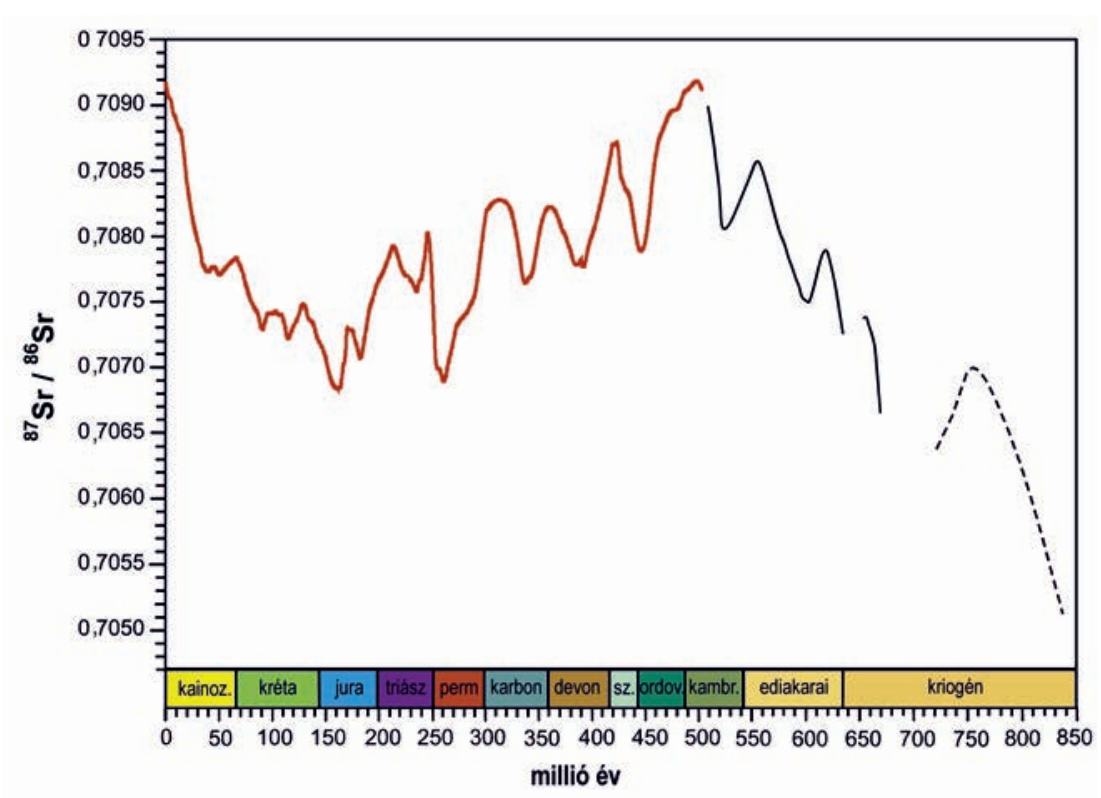

4. ábra. $\mathrm{A}^{87} \mathrm{Sr}{ }^{186} \mathrm{Sr}$ arány egyik legfrissebb referenciagörbéje a fanerozoikumra és a neoproterozoikum második felére (MCARTHUR et al. 2012 alapján)

Figure 4. A recently compiled global Late Proterozoic and Phanerozoic ${ }^{87} \mathrm{Sr}{ }^{186} \mathrm{Sr}$ reference curve (from MCARTHUR et al. 2012)

\section{${ }^{87} \mathrm{Sr} /{ }^{86} \mathrm{Sr}$ arány használata kormeghatározásra}

\section{A referenciagörbe}

A Sr-izotóparányok sztratigráfiai felhasználhatóságához elengedhetetlen egy standard referenciagörbe megléte, amellyel az ismeretlen korú mintán mért ${ }^{87} \mathrm{Sr} /{ }^{86} \mathrm{Sr}$ arányt összevethetjük. A referenciagörbe megalkotásáhozjó megtartású, gazdag makrofaunával (illetve fiatalabb képződményeknél gyakran mikrofaunával) rendelkezô, ezáltal pontosan ismert korú rétegsorokból vett minták mérése alapján állapítják meg a ${ }^{87} \mathrm{Sr} /{ }^{86} \mathrm{Sr}$ arány változását az adott időszakaszra. A meghatározandó minták korolásában a pontosságnak gátat szab a referenciagörbe meredeksége az adott intervallumban. Kedvező esetben, például a kainozoikumban az utolsó $40 \mathrm{M}$ év során meredeken emelkedó görbe mentén \pm 1 M éven belüli felbontás is elérhetó (RAvizZA $\&$ ZACHOS 2003). körben használt, immár a késô-proterozoikumra is kiterjesztett referenciagörbét MCARTHUR et al. (2012) közölték, minden eddiginél több, 4119 adatpontra alapozva (4. ábra).

\section{Statisztikai módszerek és a LOWESS illesztés alkalmazása}

$\mathrm{Az}$ ismert biosztratigráfiai helyzetû mintákon mért ${ }^{87} \mathrm{Sr} /{ }^{86} \mathrm{Sr}$ értékeket háromféleképpen alakíthatjuk át ahhoz, hogy a nyers adatokból megkapjuk a simított izotópgörbét, ezek a módszerek a (1) lineáris regresszió, (2) analitikai polinomok és (3) paraméter nélküli regressziós modell alkalmazása (MCARTHUR 1994). Ez utóbbi bizonyult a legjobb illesztési módnak, ami nem feltételezi a ${ }^{87} \mathrm{Sr} r{ }^{86} \mathrm{Sr}$ és a számszerú kor közötti kapcsolat milyenségének ismeretét. A LOWESS illesztés (Locally Weighted Scatterplot Smoother) egy hatékony, paraméter nélküli regressziós módszer, melyet Cleveland (1979) fejlesztett ki, majd 
HOWARTH \& MCARThuR (1997) alkalmazta elóször a Sr izotóp-összetétel változásának kezelésére. A módszer segítségével a ${ }^{87} \mathrm{Sr} /{ }^{86} \mathrm{Sr}$ arány a használt számszerú időskálába konvertálható, megteremtve a ${ }^{87} \mathrm{Sr} /{ }^{86} \mathrm{Sr}$ és a kalibrált biosztratigráfiai vagy magnetosztratigráfiai skálák közötti összevetés lehetôségét (MCARTHUR et al. 2001). Mivel nem létezik olyan függvény, amellyel a számszerú kor a Sr izotópadatokból kiszámítható lenne, ezért referenciatáblázat (look-up table) felállítása volt szükséges.

$\mathrm{A}^{87} \mathrm{Sr} /{ }^{86} \mathrm{Sr}$ arányt nem független változóként kezelve az y tengelyhez rendeljük, az $\mathrm{x}$ tengelyen pedig az években kifejezett kort adjuk meg. Az n elemú adathalmazra illeszkedő simított görbe elő́llítása az alábbi lépésekből tevődik össze (HowARTH \& MCARTHUR 1997): (1) a simító paraméter definiálása az összadatszám hányadosaként; (2) az y tengellyel $\left({ }^{87} \mathrm{Sr} /{ }^{86} \mathrm{Sr}\right)$ párhuzamosan a simító paraméterrel megegyezô szélességú ablak elhelyezése minden egyes adatpontra az x tengely (kor) szerint növekvő sorrendben; (3) minden egyes alkalommal az ablak központjában levő $\mathrm{x}_{0}$ értékhez tartozó átlag y érték legjobb közelítése lokális regresszióval, vagyis az ablakon belüli ${ }^{87} \mathrm{Sr} /{ }^{86} \mathrm{Sr}$ értékének illesztése az abszolút kor négyzetes függvényeként, a súlyozott legkisebb négyzetes regresszió módszerét felhasználva (MCARTHUR et al. 2001). Ezen a módon minden egyes ablakra megadható a becsült ${ }^{87} \mathrm{Sr} r{ }^{86} \mathrm{Sr}$ érték, vagyis a LOWESS illesztés minden egyes koradatra számítható legjobb ${ }^{87} \mathrm{Sr} r{ }^{86} \mathrm{Sr}$ közelítések sorozatából áll (HOWARTH \& MCARTHUR 1997). Mivel az illesztés alapja nem függvénykapcsolat, ezért nem létezik egy olyan egyenlet, melynek segítségével számszerú kort lehetne számolni a ${ }^{87} \mathrm{Sr} /{ }^{86} \mathrm{Sr}$ arányból (MCARTHUR 1994).

\section{A Sr izotópgörbe változó trendjei a földtörténet során}

Bár a tengervíz ${ }^{87} \mathrm{Sr} /{ }^{86} \mathrm{Sr}$ aránya és az idố közötti, WICKMAN (1948) által megjósolt lineáris összefüggés nem bizonyult valósnak, jellegzetes trendek megfigyelhetôek a földtörténet egyes szakaszai során (VEIZER 1989). Az elsô alapvető változás az archaikum és a proterozoikum történt. Míg az archaikumi karbonátokból nyert ${ }^{87} \mathrm{Sr} /{ }^{86} \mathrm{Sr}$ arány megközelíti a köpenybeli arányt, addig a proterozoikumban már egyértelmúen nagyobb a radiogén Sr aránya. Ezt a jelenséget először a ${ }^{87} \mathrm{Sr}$-ban dúsabb kontinentális kéreg archaikumi hiányával magyarázták (VEIZER \& COMPSTON 1976), ezt azonban késốbb VEIZER et al. (1982) cáfolták. Ugyan a kontinentális területek nagysága csupán harmada lehetett a mainak, a folyóvízi beszállitás mégis jelen volt a Sr-rendszerben, de eltörpült az ennél jóval dominánsabb, az összes Sr-forrás 80-90\%-át kitevő hidrotermális beáramlás mellett, mely az óceáni kéreg és a tengervíz kölcsönhatásából eredt. A földtörténet korai szakaszában a mainál sokkal magasabb hőáram érkezett a felszínre a köpeny felől, és ehhez intenzívebb hidrotermális rendszer kötődött, amely átalakította a ${ }^{86} \mathrm{Sr}$-dús bazaltot. VEIZER \& COMPSTON (1976) szerint minden archaikumi karbonátos kőzeten mért ${ }^{87} \mathrm{Sr} /{ }^{86} \mathrm{Sr}$ érték párhuzamba állítható azzal egyidős felsóköpeny Sr izotóp-összetétellel. A köpeny- eredetú geokémiai jellegeket mutató óceánt felváltotta a folyóvízi beszállítás dominálta rendszer 2,5 $\pm 0,3$ milliárd év körül, az archaikum-proterozoikum átmenete táján (VEIZER 1989), amikor a hőáram lecsökkent, valamint a kontinensek területe is megnôtt (5. ábra), hozzájárulva a ${ }^{87} \mathrm{Sr} r{ }^{86} \mathrm{Sr}$ arány hirtelen megemelkedéséhez. Különösen 2,5-2,1 Ga között nőtt jelentősen ${ }^{8}{ }^{87} \mathrm{Sr}$ aránya a karbonátokban, majd ezután a proterozoikum végéig a növekedés üteme kisebb.

A fanerozoikumban $\sim 500 \pm 200$ millió éves periódusú másodrendú oszcillációhoz tartozó mintázat is megfigyelhető a ${ }^{87} \mathrm{Sr} /{ }^{86} \mathrm{Sr}$ arányban (VEIZER 1989). A paleozoikumban és a mezozoikum elején az óceánközépi hátságok megnövekedett aktivitása miatt az arány csökkent, majd a krétától kezdve nôtt a ${ }^{87} \mathrm{Sr}$ mennyisége, mivel az alpi orogenezis, azon belül a paleogéntől kezdve a Himalája és a Tibeti-plató kiemelkedése nagyon intenzív mállást indított el (RAYMO \& RUDDIMAN 1992).

Az adatsorban millió éves léptékú, harmadrendú fluktuáció is megfigyelhető, pl. DePaolo (1986) a Tasmántengerbốl származó mélytengeri fúrómagból vett mintákon a kora-miocéntől a késó-pleisztocénig a ${ }^{87} \mathrm{Sr} /{ }^{86} \mathrm{Sr}$ arány változásaiból transzgressziós-regressziós, valamint glaciális-interglaciális ciklusokat is kimutatott. Ezt az elvet követ-

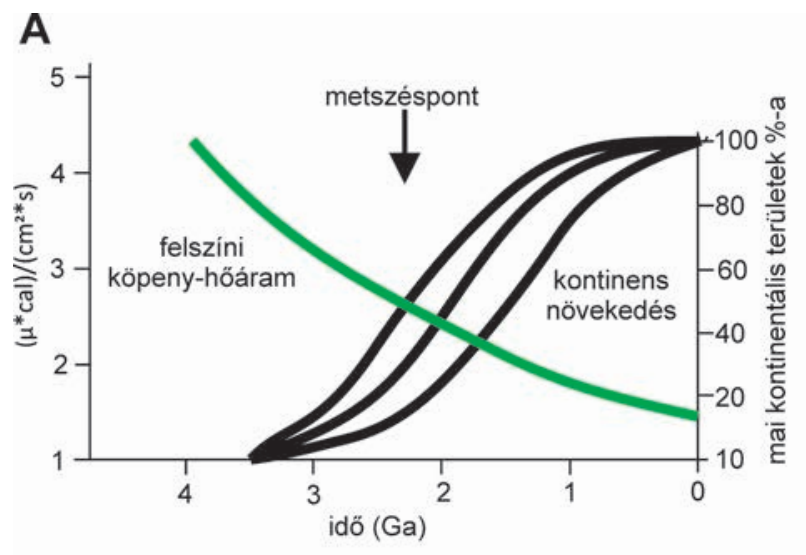

B

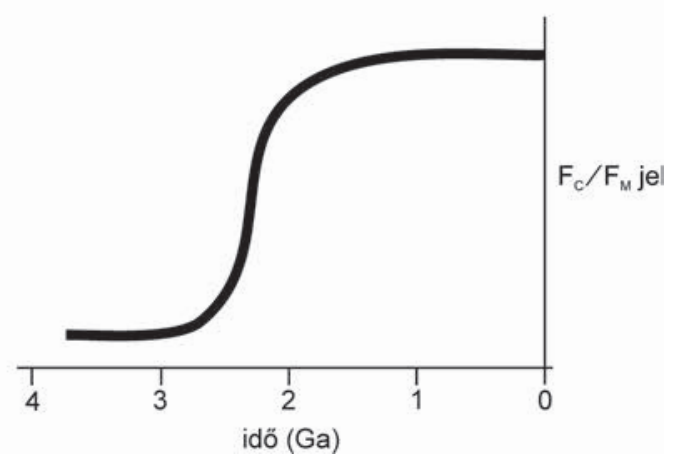

5. ábra. A tengeri Sr izotóparány elsődleges trendjét meghatározó tényezők (A) és a tengervízbe jutó $\mathrm{Sr}$ forrásainak változása a földtörténet során (B). A 2,5 Ga megfigyelhető váltás a köpenyeredetủről ( $\mathrm{FM})$ a kontinentális lefolyás (FC) által dominált Sr-rendszerre (B) egybeesik a höáram és kontinensnövekedési görbék metszéspontjával (A) (VEIZER et al. 1982 alapján)

Figure 5. First-order controls (A) and sources of marine $\mathrm{Sr}(B)$ determining the main trend in Sr isotopic evolution through Earth history. The change at $2.5 \mathrm{Ga}$ from predominantly mantle-derived (FM) to continental (FC) Sr flux (B) is coindicent with the intersection of curves of heat flux and continental growth $(A)$ (after VEIZER et al. 1982) 
ve LUDWIG et al. (1988) megvizsgálta az Enewetak-atollt és hasonló összefüggést tudott kimutatni a Sr izotópgörbe és az atoll életében bekövetkezett, geológiai időskálán nézve rövid idejú változások között.

Elméletileg millió éven belüli, negyed- vagy magasabb rendû fluktuációk is kimutathatók, hiszen a domináns Srforrások fluxusainak $10^{4}$ éven belüli változásai is megőrződhetnek. Roveri et al. (2014) a messzínai sókrízis üledékeit vizsgálva mutattak ki 200 ezer éven belüli változásokat a Sr izotóprekordban.

\section{Esettanulmányok a SIS felhasználására}

A SIS módszer mára számos kutatási területen igazolta a benne rejlő lehetőségeket. Az alábbi példákon keresztül bemutatjuk, hogy alkalmazása többek között hogyan támogatja az egyedi, hirtelen bekövetkező földtörténeti események értelmezését, illetve segítséget nyújt a jó korjelző ősmaradványokban szegény, sekélytengeri karbonátos képződmények korolásában.

\section{Jenkyns-esemény}

Az óceáni anoxikus események (OAE) jelenségét SCHLANGER \& JENKYNS (1976) ismerte fel először. Az egyik legtöbbet kutatott ezek közül a kora-toarci ( 183 M év) Jenkyns-esemény (MüLLER et al. 2017), avagy hagyományos nevén a Toarci Óceáni Anoxikus Esemény (T-OAE). Ennek üledékeit csak korábbi selfterületekről, kontinens szegé- lyekról, mai szárazföldi feltárásokból, illetve mélyfúrásokból ismerik, mivel alsó-jura óceáni kéreg rátelepült üledékkel nem ôrződött meg a Földön. Az esemény jelentős mennyiségú szerves anyagban gazdag feketepala-képződéssel és az egykori óceán elemi összetételében és egyes izotóprendszereiben kimutatható geokémiai anomáliákkal jellemezhetô (JENKYNS 2010). Mint minden OAE-t, a Jenkyns-eseményt is a nagy szervesanyag-tartalmú rétegek alapján definiálták. Az eseményt a $\delta^{13} \mathrm{C}$ izotópgörbén markáns negatív kilengés jelzi, mely a könnyebb C-izotóp nagy mennyiségú hozzáadódására utal (pl. MüLLER et al. 2017).

A földtörténet során bekövetkezett óceáni anoxikus események rendre hőmérsékleti maximumokkal és humid klímaszakaszokkal esnek egybe (JENKYNS 2003). Ezt az elméletet mind a ${ }^{187} \mathrm{Os} /{ }^{188} \mathrm{Os}$, mind a ${ }^{87} \mathrm{Sr} /{ }^{86} \mathrm{Sr}$ adatok alátámasztják a T-OAE idején. A két hasonló izotóprendszer az esemény idején a radiogén izotóp megnövekedett arányát mutatja, ami az intenzívebb hidrológiai ciklus következtében a kontinentális kéreg nagyobb mértékú mállására utal.

BAILEY et al. (2003) késő-pliensbachi-kora-toarci, Yorkshire-i és délnyugat-németországi belemniteszeket vizsgáltak meg. A Mg/Ca arányokból és a $\delta^{18} \mathrm{O}$ adatokból arra következtettek, hogy az adott időszakaszban $\sim 0,01{ }^{\circ} \mathrm{C} /$ ezer év sebességú, összesen 6-7 ${ }^{\circ} \mathrm{C}$-os hőmérsékletváltozás következett be, melyet $2,5 \%$ o-es sótartalom-csökkenés kísért. Az északnyugat-európai selfen kialakult nagy kiterjedésú és sekély epikontinentális tengert a monszun-dominálta éghajlat miatt bőséges kontinentális beszállítás érte, amit a Sr izotóprekordban megnövekedett radiogén Sr-tartalom is bizonyít (6. ábra). A befolyó édesvíz mennyisége miatt szalinitás

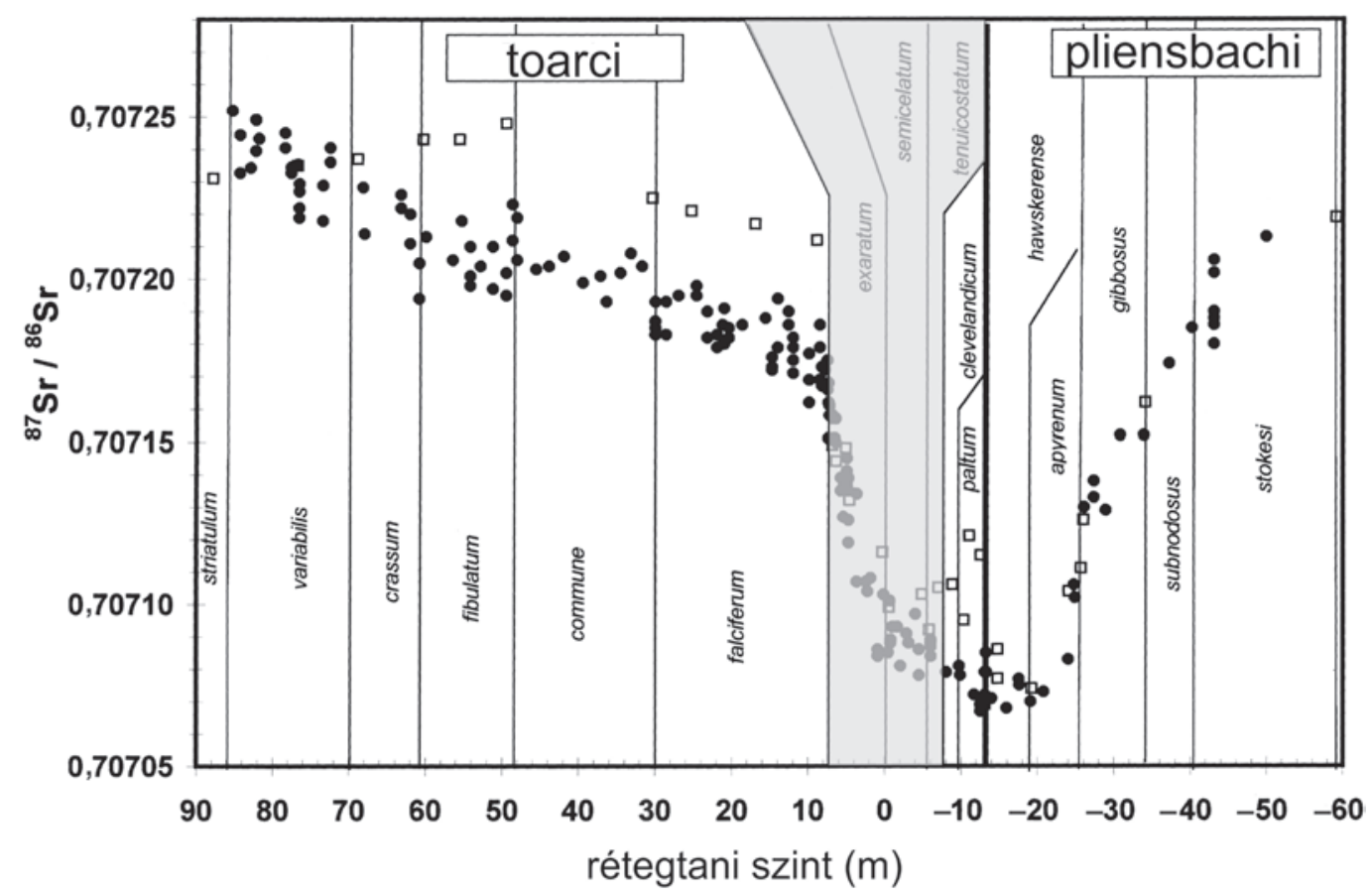

6. ábra. $\mathrm{A}^{87} \mathrm{Sr} /{ }^{86} \mathrm{Sr}$ változása az alsó-jura pliensbachi-toarci emeletekben és a Jenkyns-esemény során a Yorkshire-i rétegsorban, ammonitesz szubzónák szerinti felbontásban (MCARTHUR et al. 2000 alapján)

Figure 6. Changes in ${ }^{87} \mathrm{Sr} /{ }^{86} \mathrm{Sr}$ through the Pliensbachian-Toarcian (Lower Jurassic), including the Jenkyns event, as recorded in the section of Yorkshire coast, resolved at the ammonite subzone level (after MCARTHUR et al. 2000) 
szerint rétegzett víztömeg alakult ki a T-OAE időtartamára. MCARTHur et al. (2000) a ${ }^{87} \mathrm{Sr} /{ }^{86} \mathrm{Sr}$ értékeket felhasználva megállapították, hogy a jelenség 0,52 millió évig tartott, és a Sr izotópgörbe \pm 0,25 millió éves pontossággal használható fel kora-toarci rétegek korolására. A számítások ebben a szakaszban a görbe kvázi lineáris lefutását, azaz az izotóparány egyenletes ütemú változását feltételezik, melynek megalapozottsága a ciklussztratigráfiai és asztrokronológiai adatokkal ütköztetve vitatott (MCARTHUR et al. 2016).

\section{Kréta-paleogén határon zajló környezetváltozások}

Alvarez et al. (1980) közismert hipotézise szerint a kréta-paleogén határon (KPB) egy $10 \pm 4$ km átmérôjû aszteroida ütközött a Földnek, ami a késóbb azonosított Chicxulub becsapódási kráter kialakulásához vezetett. Az innen felszabaduló por szétterült a sztratoszférában, ezáltal hoszszú időre elzárva a fotoszintézishez szükséges fény útját, aminek eredményeként a tápláléklánc összeomlott és bekövetkezett a kihalási esemény. A KPB környezetváltozásainak folyamatai és a kiváltó oka vagy okai azóta is élénk tudományos vita és intenzív kutatások tárgya.

A kréta-paleogén határon észlelhető rövid időtartamú, $1 \times 10^{-4}$ nagyságrendư ${ }^{87} \mathrm{Sr} /{ }^{86} \mathrm{Sr}$ anomáliát először HESS et al. (1986) írták le. Nem tartották valószínúnek, hogy a kiugrást a Sr izotópgörbén pusztán az aszteroida anyaga, vagy a becsapódást követő vaporizáció okozta volna. Kutatásukat azonban megnehezítette, hogy akkor még nem ismerték a becsapódás helyét.

Annak érdekében, hogy konszenzus szülessen a becsapódás hatásáról a tengeri Sr izotóp-összetételt illetően, VonHOF \& SMIT (1997) újravizsgáltak két, a KPB-t átívelő, nagy üledékképződési rátájú szelvényt (Bidart, Francia- ország és a később globális sztratotípusnak kijelölt El Kef, Tunézia), mely alapján a referenciagörbét is pontosították a késő-maastrichti-kora-dániai intervallumra. A ${ }^{87} \mathrm{Sr} /{ }^{86} \mathrm{Sr}$ görbe két kiemelkedést mutat: 0,3-0,4 M évvel a KPB előtt, amely a Dekkán-trap vulkanizmusához köthetô, illetve az időszakhatáron. A második, rövid 0,00006 nagyságú kiugrás 3-4 méterrel kezdődik a KPB alatt, és $~ 1$ méterrel felette ér véget (7. ábra). Ezt a jelenséget diagenetikus kiegyenlítésnek tulajdonították, vagyis a magas kora-dániai értékeket csökkentette a diagenetikus átalakulás hatása, ahogyan a radiogén Sr-tartalmú pórusvíz tovább migrált a rétegsorban lefelé, ezáltal megemelve a határhoz közeli késő-maastrichti értékeket. VoNHOF \& SMIT (1997) szerint csak a késő-kréta, korábban arid talajok hirtelen eróziója okozhatott ekkora anomáliát a tengeri Sr izotóp-összetételben. Ugyanis ezek a talajok jelentős rezervoárjai voltak a mállásból származó Sr-nak, az átlagos 375 ppm-hez képest jóval magasabb, 500-2000 ppm Sr-tartalommal (TAYLOR 1965). A hirtelen bekövetkezett intenzív esőzések, különösen a kezdetben savas eső hatására ezek a talajok hamar elvesztették Sr-tartalmukat, amely a folyók által eljutott az óceánokba, ezáltal okozva a kilengést a görbén.

Azonban VoNHOF et al. (2011) szerint a kilengések oka a vizsgált foraminiferákat különböző mértékben ért diagenetikus felülbélyegzés. A maastrichti emeletre vonatkozó nagy felbontású ${ }^{87} \mathrm{Sr} /{ }^{86} \mathrm{Sr}$ görbét az ENCI bányából (Maastricht, Hollandia) származó, a Gulpen és Maastrichti Formációba sorolható, belemnitesz rosztrumokon végzett vizsgálatokra alapozták. Ezek alapján megállapították, hogy az alsó-maastrichti és felső-maastrichti határon elhelyezkedő inflexiós pont a ${ }^{87} \mathrm{Sr} /{ }^{86} \mathrm{Sr}$ görbén, amely a C31R magnetokronhoz kötődik, lehetőséget nyújt biosztratigráfiai korrelációra akkor is, ha magnetosztratigráfiai módszerek nem alkalmazhatók.

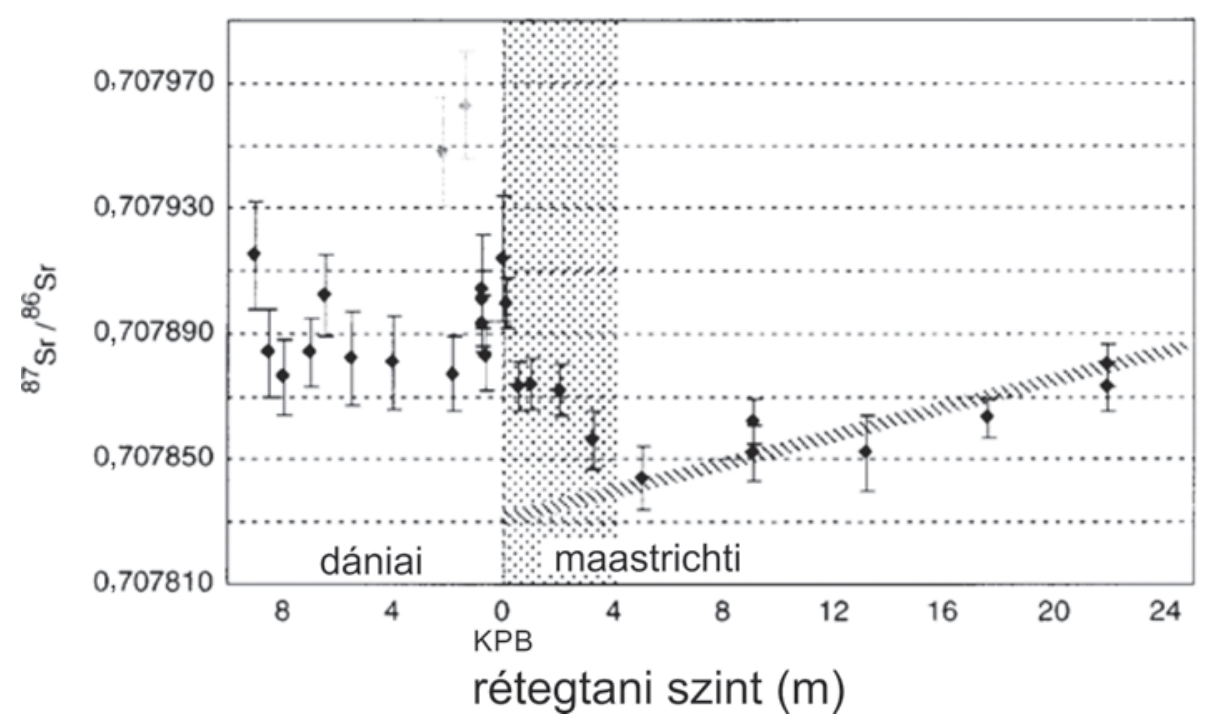

7. ábra. ${ }^{87} \mathrm{Sr} /{ }^{86} \mathrm{Sr}$ adatok a tunéziai El Kef kréta-paleogén határszelvényből. A pontozott sáv jelöli a diagenetikus hatás által érintett szakaszt (VoNHOF \& SMIT 1997 alapján)

Figure $7{ }^{87} \mathrm{Sr} /{ }^{86} \mathrm{Sr}$ measurements from the Cretaceous-Palaeogene boundary section at El Kef(Tunisia). Dotted band denotes the interval of diagenetic effect (after VONHOF \& SMIT 1997) 
A kréta-paleogén határintervallumban két markáns maximumot írtak le. Az egyik csúcs a határ előtt kb. 300000 évvel figyelhető meg, és egyes szerzők egy innen kezdődő hosszú távú, csökkenô trendrôl írnak kb. 55 M évig (MCARTHur et al. 2001, DAs et al. 2006). Más tanulmányok ezen kívül pontosan a kréta-paleogén határon egy második pozitív, rövid ideig tartó csúcsot is kimutatnak (VONHOF \& SMIT 1997, MACLEOD et al. 2001), melyet azonban nem mindenütt sikerült észlelni (MCARTHUR et al. 1998). Ezt a második csúcsot többféleképpen értelmezték. DESSERT et al. (2001) a Dekkán bazaltvulkanizmusa által kiváltott felmelegedés nyomán megnövekedett mállás hatásának vélik a Sr izotóparány növekvő értékeit. Modellezési eredményeik jó egyezést mutatnak MARTin \& MACDougall (1991) adataival, akik egy maximum 3 M év hosszú csúcsot dokumentáltak. Mások szerint viszont ez a csúcs ennél rövidebb időt, legfeljebb 10000 évet reprezentál. VonHOF \& SMIT (1997), illetve MACLEOD et al. (2001) ilyen rövid idejűnek tartják az általuk dokumentált 0,00006, illetve 0,00003 mértékú csúcsot. Míg VoNHOF \& SMIT (1997) a savas esők és a csapadékosabbá váló éghajlat összhatásával indokolta a nagy kilengést, MACLEOD et al. (2001) szerint az általuk leírt kisebb kilengés jelentősebb klímaváltozás nélkül, csupán a becsapódás utáni savas esőknek a talajok mállására gyakorolt hatásával is magyarázható. Ebben a tanulmányban a kréta-paleogén események hatásának vizsgálata mellett a Sr izotópos jelet a fúrási rétegsorban előforduló foraminiferák áthalmozottságának igazolására is fel tudták használni. A határ felett is megjelennek a krétából ismert foraminifera fajok, ezek azonban a határ alatt előfordulókkal megegyező ${ }^{87} \mathrm{Sr} /{ }^{86} \mathrm{Sr}$ arányúak, viszont a csak a határ felett előforduló paleogén formáktól egyértelmúen különböznek. Ez bizonyítja, hogy a kréta fajok nem élték túl a határon lezajló eseményeket, csupán az üledékek áthalmozódása során kerültek a fiatalabb rétegbe.

DAs et al. (2006) több, a mai Dekkán-plató bazaltvidékére eső vízgyújtőjû folyórendszer oldott Sr-koncentrációját és ${ }^{87} \mathrm{Sr} /{ }^{86} \mathrm{Sr}$ arányát vizsgálták. A Dekkán Trapról származó Srfluxust összevetették a folyók globális Sr-fluxusával, a Dekkán Trap területi elterjedését a globális vízgyújtő területekhez hasonlítva. Számításaik szerint a Sr izotóparány csökkenô trendje akkor érhető csak el, ha a múltban a Dekkán mállása sokkal intenzívebb volt a mainál. Ez valószínúsíthetô, mert közvetlenül a bazaltok kiömlése után nagyobb volt azok területi elterjedése, a mállékonyságot pedig fokozta a növényzet és talajtakaró hiánya, illetve a mainál melegebb éghajlat. Összefoglalva, a kréta-paleogén határszelvények vizsgálatából származó és a modellezési eredmények egyértelmúsítik mind a Dekkán vulkanizmus, mind a Chicxulub becsapódási esemény fontos szerepét.

\section{Sr izotóparány-változások az eljegesedések során}

A késő-kainozoikumi Sr-görbe értelmezésének egyik fontos részét képezi az eljegesedések Sr-fluxusra gyakorolt hatásának figyelembe vétele. A jégkorszak során a morénák képződése növeli a kontinentális ${ }^{87} \mathrm{Sr}$-fluxust, ugyanakkor amennyiben a szilikátok mállása mellett a karbonátmállás is jelentős, akkor a ${ }^{87} \mathrm{Sr} /{ }^{86} \mathrm{Sr}$ emelkedése kisebb mértékú (RAVIZZA \& ZACHOS 2003). A Sr hosszú óceáni tartózkodási ideje következtében viszont a nagy frekvenciájú (<100 000 év periódusú) eljegesedési ciklusok nem okoznak számottevő változást a Sr izotópgörbén (HENDERSON et al. 1994).

A Sr-izotópos jelnek az oxigén izotóparánnyal, mint az eljegesedések proxyjával való összehasonlítása alapján a kettő között nincs szisztematikus kapcsolat. OsLICK et al. (1994) oligocén-miocén minták esetében a ${ }^{87} \mathrm{Sr} /{ }^{86} \mathrm{Sr}$ emelkedést 1-1,5 millió évvel a $\delta^{18} \mathrm{O}$ csökkenés, tehát az Antarktisz eljegesedésének visszaszorulása után dokumentálták. A Sr izotóprendszer késleltetett válaszát az elemek eltérô tartózkodási idejével magyarázták, amihez hozzájárulhatott a szilikátok mállásának az interglaciálisok alatti maximuma is. A vizsgált periódusban az interglaciálisok utáni ${ }^{87} \mathrm{Sr} /{ }^{86} \mathrm{Sr}$ növekedésen kívül egy általánosan növekvő trend is megfigyelhető, amely azonban nem a glaciális ciklusokhoz, hanem tektonikai folyamatokhoz köthető (RAYMO \& RUDDIMAN 1992). Ezzel az értelmezéssel összhangban vannak Hodell et al. (1990) számításai, miszerint az elmúlt 2,5 millió év során bekövetkező ${ }^{87} \mathrm{Sr} /{ }^{86} \mathrm{Sr}$ növekedésnek csupán 25\%-a vezethetô vissza a glaciális erózióra.

Az eljegesedések és a ${ }^{87} \mathrm{Sr} /{ }^{86} \mathrm{Sr}$ jel viszonya sokkal idősebb minták esetében is fontos, mert a SIS egyrészt jelentős szerephez juthat a prekambriumi biosztratigráfia korlátozott lehetőségei miatt, másrészt hozzájárulhat az eljegesedések okának megértéséhez. SAWAKI et al. (2010) neoproterozoikumi-kambriumi rétegsorokat vizsgáltak Skóciában. A legalsó glaciális együttes korát az azt megelőző kőzetek ${ }^{87} \mathrm{Sr} /{ }^{86} \mathrm{Sr}$ értékeinek segítségével tisztázták, és így társították a Hógolyó Föld legidősebb, sturti eljegesedéséhez. A legkorábbi glaciális üledékek előtt csökkenő ${ }^{87} \mathrm{Sr} /{ }^{86} \mathrm{Sr}$ trend rajzolódik ki, a glaciális összlet alatti minimummal. Ezt a változást a Sr izotópgörbén a Rodinia feldarabolódásához is vezető vulkanizmus bazaltjainak mállásával magyarázzák. 825 és 755 M év között számos bazaltos provincia alakult ki és az óceáni hátságok hossza is nőtt (GoDDÉRIs et al. 2003), melyek mállása hatással volt a tengervíz ${ }^{87} \mathrm{Sr} /{ }^{86} \mathrm{Sr}$ arányára. A nagy mértékú mállásnak Sr izotóprendszeren kívül a klímára is hatása volt, és a légköri $\mathrm{CO}_{2}$ szint csökkentése révén döntő szerepet játszott az eljegesedés kialakulásában. Rodinia szuperkontinens feldarabolódása után megnövekedett a csapadékosság mértéke és ezáltal a folyóvízi lefolyás, ami pedig növelte a mállást. DoNNADIEU et al. (2004) modell számítások segítségével összehasonlította a csupán a Rodinia feldarabolódásából adódó hatást, illetve a kontinens konfiguráció változásának és bazaltok mállásának együttes hatását a $\mathrm{CO}_{2}$ koncentrációra, kimutatva, hogy az utóbbi nagyobb csökkenést eredményez a $\mathrm{CO}_{2}$ szintben.

\section{Karbonátplatformok korolása}

A karbonátplatformok biosztratigráfiai tagolása sok esetben problémás, mert a sekélyvízi környezetben ritkák a jó korjelző ősmaradványok. A biogén karbonátok és a mész- 
vázú ősmaradványok viszont ígéretes lehetőséget nyújtanak a SIS alkalmazására. Elsố példánk a középsô-miocén sokak által vizsgált időszakával kapcsolatos, ami az utolsó 35 millió év legmelegebb intervalluma. A középső-miocén klímaoptimumot 17-13,5 M évre (csúcsát 17-15 M évre) datálják (ZACHOS et al. 2001). Ezen belül a $\delta^{13} \mathrm{C}$ izotópgörbén markáns pozitív anomália mutatható ki, amit Montereyeseménynek neveznek. BRANDANO et al. (2017) kutatásai annak megismerésére irányultak, hogy hogyan reagált a környezetváltozásokra a karbonátplatform, kimutatható-e a Középső-Mediterrán térségben a szénizotóprekord alapján a Monterey-esemény. A Latium-Abruzzi-platformon Pietrasecca szelvényéből 15 mintát gyújtöttek SIS vizsgálatok számára, ezek közül petrográfiai és geokémiai vizsgálatok szúrése nyomán 8 mintán végeztek Sr izotópmérést. Mind a petrográfiai mikroszkópos vizsgálatok (8. ábra), mind a nyomelem-összetétel (Mg-, Sr-, Fe-, Mn-koncentráció) arra utalt, hogy az elemzésekhez használt Pecten kagylóhéjak anyaga nem kristályosodott át. platformperem progradációjának ütemét $(2,5 \mathrm{~km} / \mathrm{m}$ év) is sikerült kiszámítani. A biosztratigráfiához visszacsatolva az eredmények segítették egyes tethysi rudista kagylók és bentosz foraminiferák rétegtani elterjedésének pontosítását is.

Hasonló de némileg idősebb képződményeket, a későkréta cenomán-campani szakaszának rétegsorait vizsgálták az Appenin-platformon FrIJIA et al. (2015). Ugyancsak jó megtartású rudista vázanyagon végzett méréseik révén a SIS-alapú kronosztratigráfiai korreláció messze meghaladta a biosztratigráfiával elért felbontást és megbízhatóságot. A platformfejlődés jobb megértésének helyi jelentőségén túl figyelemre méltó, hogy a SIS közvetítésével a sekélytengeri képződmények bentosz foraminifera zonációja párhuzamosítható a standard ammonitesz zonációval, illetve a platform karbonátos rétegsorainak szénizotópgörbéje szintén jó egyezést mutat a nyílttengeri üledékekből, pl. az angliai írókréta fáciesû rétegsorokból származó adatokkal. A távoli szelvények között is jól megfeleltethető
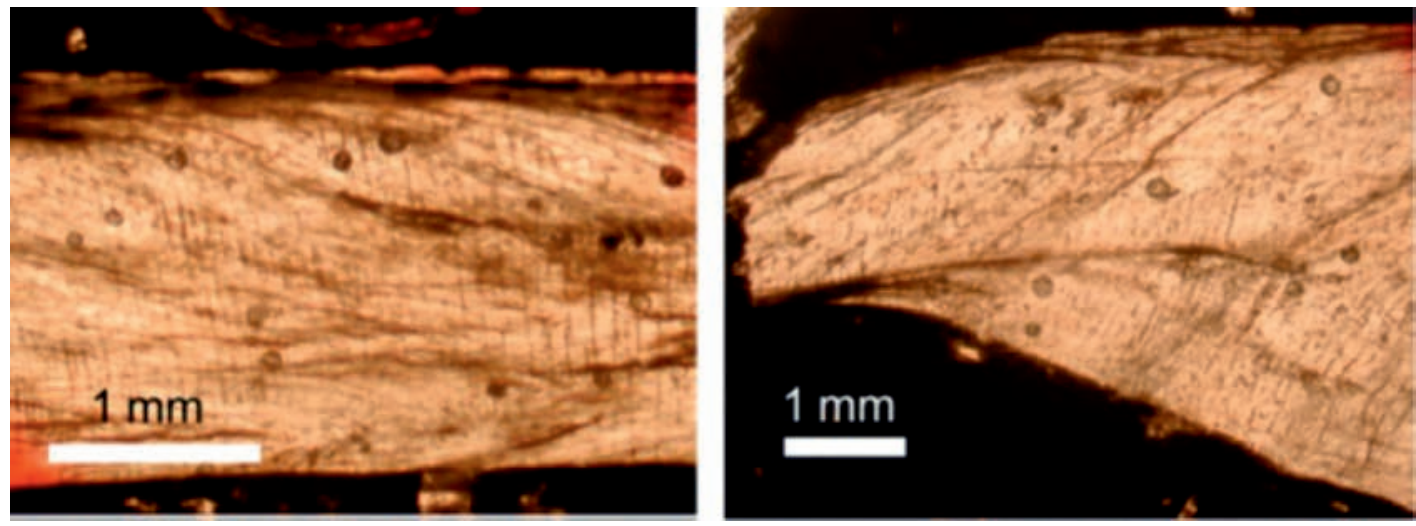

8. ábra. Vékonycsiszolatos kép a jó megtartású és Sr mérésre alkalmas Pectinidae kagylóvázak mikrolemezes héjszerkezetéröl (BRANDANO et al. 2017)

Figure 8. Thin sections of well-preserved pectinid bivalve shells selected for Sr measurements, showing pristine foliated microstructure (BRANDANO et al. 2017)

$\mathrm{A}^{87} \mathrm{Sr} /{ }^{86} \mathrm{Sr}$ arányokhoz MCARTHUR et al. (2001) referenciatáblázata alapján rendeltek számszerú korokat, melyek alapján egyértelmúen igazolható egyrészt a platform karbonátos rétegsorain mért pozitív szénizotóp-anomália korrelációja a Monterey-eseménnyel, másrészt az eseménynyel összefüggésben kimutathatók az üledékképződési ráta markáns változásai a platformon.

A kréta időszak nagy kiterjedésú karbonátplaformjainak kormeghatározása hagyományosan a rudista kagylók és bentosz foraminiferák biosztratigráfiáján alapul, de a hoszszú fajöltők okozta kis felbontás és az egyes szelvények között ellentmondásosnak bizonyuló elsô és utolsó megjelenési dátumok visszatéró problémát jelentenek. A nagy kiterjedésú tethysi karbonátplatformok közül az AdriaiDinári platform Brač-szigeti felsô-kréta rétegsorainak SIS általi korolását rudista vázanyagon végezték el (STEUBER et al. 2005). A koradatok segítségével megadták a platform fejlődésének coniacitól maastrichtiig terjedő kronosztratigráfiai keretét, és vizsgált szelvények térbeli eloszlásával együtt a szénizotóp-anomáliák közül a legnagyobb amplitúdójú és legfontosabb a cenomán-turon határon zajlott OAE2 (más néven Bonarelli-esemény) pozitív kilengése, ami globális jellegénél fogva a platformon és a nyíltvízi környezetekben egyaránt éreztette hatását.

A magyarországi kréta képződmények SIS vizsgálata is ígéretesen elkezdődött. A Bakonyban PARENTE et al. (2013) előzetes eredményei megerôsítik és pontosítják az Ugodi Mészkő campani korát.

\section{A Paratethys miocén sztratigráfiája}

A késő-paleogén és a neogén során a dinamikusan alakuló alp-kárpáti orogén környezetében változó mértékben elszigetelt beltenger, a Paratethys, majd a belőle kialakuló Pannon-tó jött létre, melyek üledéksora az élővilág különböző mértékú endemizmusa miatt csak korlátozottan korrelálható a globális kronosztratigráfiai skálával. Emiatt az 1960-as évek végétől kezdve a Középső-Paratethys 
területére regionális emeletrendszert dolgoztak ki, melynek korrelációja máig folyamatosan fejlődik (PILLER et al. 2007, KovÁč et al. 2018). Ebben a regionálisan fontos problémakörben a SIS alkalmazása egyrészt a biosztratigráfiai alapú korreláció ellenőrzését és bizonytalanságának csökkentését teheti lehetôvé, másrészt a módszer sajátos korlátaiba ütközhet olyankor, amikor a világtengerrel való kapcsolat beszúküilése gátolta a teljes vízkeveredést és a globálistól eltérô Sr izotóparányhoz vezetett. Ez utóbbi esetben a SIS rétegtani használhatóságának csökkenése viszont az ősföldrajzi és paleoóceanográfiai rekonstrukciók számára hordozhat hasznos információt, független adatokat szolgáltatva a medence elszigetelődési eseményeihez. Az új hazai eredmények várható részletes publikálása előtt (LESS \& FrIJIA 2015, LESS et al. 2015) hasznos lehet áttekinteni a régióból eddig ismertetett eredményeket.

Az elmúlt 25 év irodalmából (GoLDSMITH et al. 1994; VenNEMANn \& HeGNER 1998; HudÁCKOvÁ et al. 2003; JANZ
\& Venneman 2005; PipPÈRR et al. 2007; Kocsis et al. 2007, 2009, 2012; FordinÁl et al. 2014; BRZOBOHATÝ et al. 2016; Kocsis 2016; Teschner \& ReICHENBACHER 2017) a felsőoligocénben induló egri emelettôl a felsô-miocén pannóniai emeletének alsó részéig terjedő intervallumból 148 publikált ${ }^{87} \mathrm{Sr} /{ }^{86} \mathrm{Sr}$ adatot gyújtöttünk össze az elektronikus melléklet E1. táblázatában. A minták mindegyike biosztratigráfia segítségével regionális emeletbe vagy alemeletbe sorolható, a Sr izotóparányokat a globális referenciagörbével egyuitt a 9. ábra szemlélteti. Területi eloszlásban a legtöbb adat a Bécsi-medencéból (59) és az észak-alpi előtéri medencéből (48) származik (az utóbbit NyugatiParatethysnek nevezik SANT et al. (2017), akiknek a Paratethys részmedencékre osztását követjük). A NógrádNovohrad-medence (15 adat) és a szlovákiai intermontán medencék (13) mellett a Kisalföldi-Duna-medencéből (7) valamint a kárpáti előtéri medencéből (6) csak szórványos adatok állnak rendelkezésre. A mérési adatok egy része nem

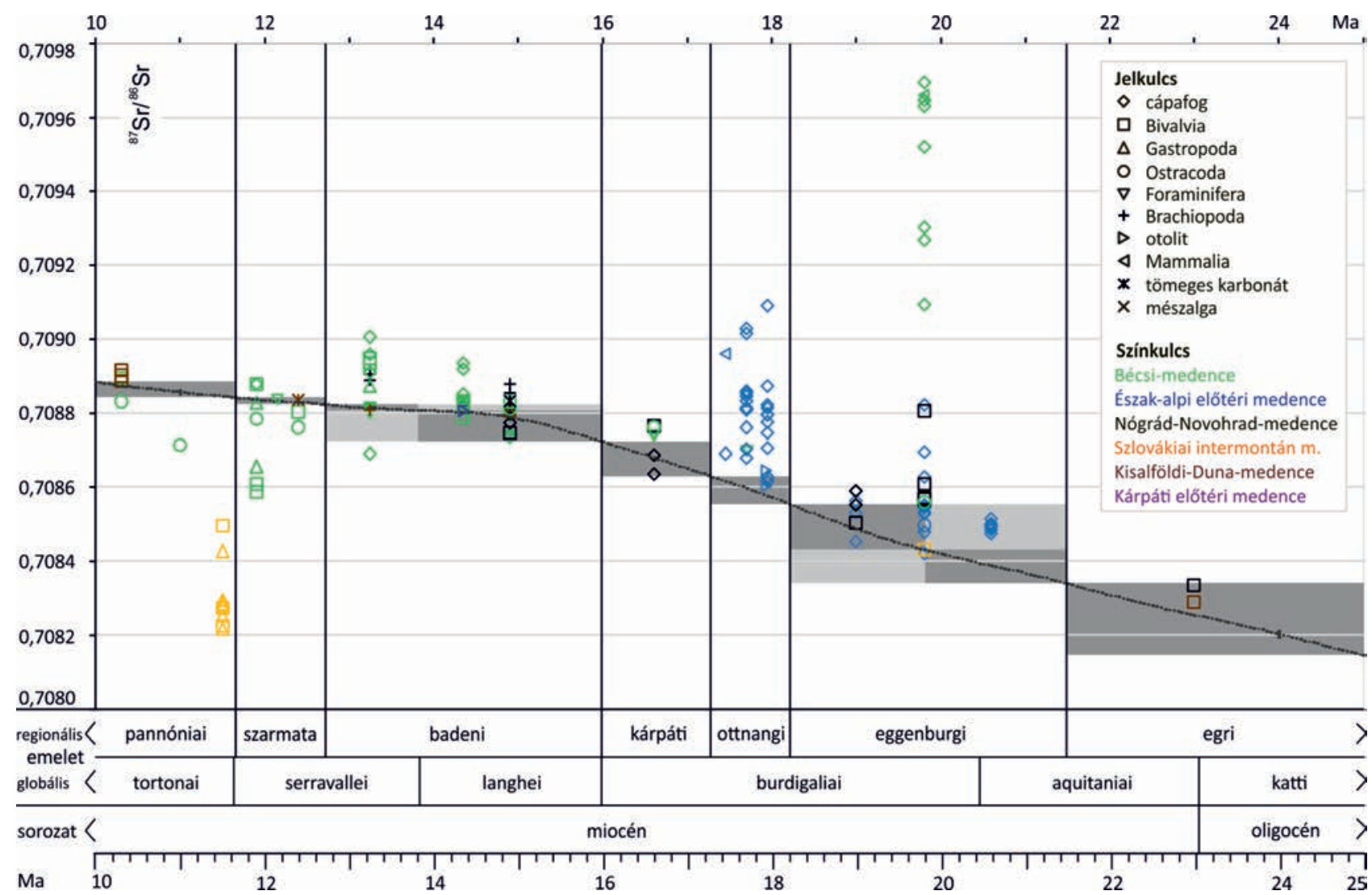

9. ábra. A Nyugati-és Középső-Paratethys egyes részmedencéiből publikált, legalább emelet szintű kronosztratigráfiai besorolású, miocén korú, különböző anyagú minták $148 \mathrm{db}$ Sr izotópadata és összhasonlításuk a globális referenciagörbével (MCARTHUR et al. 2012). A minták korát az adott emelet vagy alemelet kortartományának középértékével adjuk meg. A referenciagörbe körüli szürke téglalapok a Paratethys emeletein belül a globális referenciagörbe alapján várható ${ }^{87} \mathrm{Sr} /{ }^{86} \mathrm{Sr}$ értéktartományt jelzik, az eggenburgi és badeni esetében alemelet felbontásban. A számszerű időskála és a regionális emeletek globális korrelációja HiLgen et al. (2012) valamint PILler et al. (2007) és Kováč et al. (2018) munkáin alapul. A referenciagörbe hibahatára 11 M évnél $\pm 0,000004$, 24 M évnél $\pm 0,000008$. Részmedencék és mintatípusok szerint válogatott adatokat ld. a digitális melléklet E1-E7. ábráin

Figure 9. Compilation of 148 published Miocene Sr isotope data from the different subbasins of the Western and Central Paratethys, chronostratigraphically resolved at least at stage or substage level, measured on different sample types, and their comparison with the global ${ }^{87} \mathrm{Sr} /{ }^{86} \mathrm{Sr}$ reference curve of MCARTHUR et al. (2012). The age of samples is given as the mean value of the age range of their assigned stage or substage. Grey rectangles around the reference curve mark the expected range of ${ }^{87}$ Sr ${ }^{86}$ Sr values within regional Paratethys stages (or substages within the Eggenburgian and Badenian) on the basis of global reference curve. The numeric time scale and the global correlation of regional Paratethys stages are based on HILGEN et al. (2012), PILLER et al. (2007) and Kovíc et al. (2018). The error of the reference curve values is $\pm 0,000004$ at $11 \mathrm{Ma}$ and \pm 0,000008 at $24 \mathrm{Ma}$. Symbol shape denotes different sample types, color denotes subbasin of sample locality. Data selected by subbasin and sample type are shown in Figures E1-E7 in the online Supplementary Material 
elsősorban SIS célú vizsgálatokból származik. A minták biogén karbonát és foszfát 10 különböző típusát képviselik, ezek a gyakoriság csökkenő sorrendjében cápafog, kagyló, csiga, ostracoda, foraminifera, brachiopoda váz, otolit, tengeriemlős-csont, tömeges karbonát, és mészalga. Az elektronikus melléklet E1-E7. ábrái a minták típusa, illetve a lelőhelyeik Paratethys részmedencék szerinti ősföldrajzi helyzete alapján elkülönítve mutatják be a Sr izotópadatok részhalmazait.

JANZ \& VENNEMANN (2005) az észak-alpi előtéri medence molassz képződményeinek ostracodáin végzett sokirányú őslénytani és geokémiai vizsgálatokat. Az orogenezishez kapcsolódó klíma- és környezeti változások kimutatása mellett a Sr izotópgeokémiai adataik igazolták a Nyugati-Paratethys összeköttetését a világtengerrel a tengeri molassz képződése idején. Az eggenburgitól a badeniig (20-13 M év) az adatok jó egyezést mutatnak a referenciagörbével, ami a szarmatában meginduló sótartalom-csökkenés nyomán megszúnik. Az ottnangiban és a badeniben az otolitok mérése alapján rendelkezésre álló néhány adat is jól egyezik a globális referenciagörbével (PIPPÈRR et al. 2007; BrZobohatý et al. 2016; TESCHNER \& REICHENBACHER 2017).

Az alpi előtéri molasszból előkerült cápafog-maradványokon nagy számban végeztek Sr izotópméréseket. A globális összevetés vegyes képet mutat: bár VENNEMANN \& HEGNER (1998) számos esetben jó egyezést talált a referenciagörbével, Kocsis et al. (2009) azonban azt igazolták, hogy a kristályos kőzetekkel jellemezhető szárazulatokról érkező folyóvízi beszállítás a világtengeri átlaghoz képest radiogén ${ }^{87} \mathrm{Sr}$-ben dúsulást eredményezett. Kocsis et al. (2007) azt is kimutatták, hogy egyes cápafajok édesvízi életmódhoz is alkalmazkodhattak, amit anomálisan alacsony ${ }^{87} \mathrm{Sr} /{ }^{86} \mathrm{Sr}$ arány jelez. Hazai vizsgálatok a Nógrádimedence eggenburgi, kárpáti és badeni korú cápafogain a referenciagörbével kompatibilis eredményt adtak, ami ezekben a korszakokban a Középső-Paratethysnek a világtengerrel való megfelelő kapcsolatára utal (Kocsis et al. 2009, Kocsis 2016).

Foszfátos vázú brachiopodákról Kocsis et al. (2012) közöltek szórványos adatokat a badeniből. Ezek némelyike illeszkedik a referenciagörbére, míg mások a vártnál magasabb értéket mutatnak, ami a pórusfolyadék okozta utólagos folyamatokkal magyarázható. Megbízhatóbb eredményekre vezetett foraminifera-vázak vizsgálata a Bécsi-medencéből (HudÁČKOVÁ et al. 2003, FoRdinÁL et al. 2014). Molluscahéjakon végzett nagy számú mérés adatait közli FoRDINÁL et al. (2014). A badeniig ezek a referenciagörbéhez illeszkednek vagy ahhoz képest magasabb izotóparányokat mutatnak, a szarmatára és a pannóniaira viszont a sótartalomcsökkenéssel összefüggésben többnyire alacsonyabb értékek jellemzőek. A fenti foraminifera és mollusca adatok közül a 20 legmegbízhatóbbat kiválogatva KovÁč et al. (2017) tettek kísérletet a Paratethys miocén rétegtanában és fejlődéstörténeti rekonstrukciójában a SIS rendszeres felhasználására. Rámutattak arra, hogy a SIS alkalmazhatósága függ a mindenkori uralkodó áramlási rendsze- rektől. A világtengerrel való vízkeveredés antiesztuarin áramlási viszonyok mellett intenzívebb, ami kedvez a paratethysi ${ }^{87} \mathrm{Sr} /{ }^{86} \mathrm{Sr}$ arányok referenciagörbére való illeszkedésének. A miocén során a referenciagörbe meredekségének csökkenése 15 M évtől globálisan csökkenti a SIS által elérhető pontosságot, majd a Paratethys részmedencéire jellemzô sótartalom-csökkenés a szarmatában, illetve a Pannon-tó teljes elszigetelődése a pannóniaiban regionálisan vet véget a SIS korrelációs alkalmazhatóságának.

\section{Összefoglalás}

A korszerú rétegtanban egyre elterjedtebben használt, a Sr radiogén és nem radiogén izotópjainak arányán alapuló módszer a Sr időbeli változásokat mutató természetbeni körforgásának a tengeri üledékes rétegsorokban megőrzôdött nyomait vizsgálja. A radiogén ${ }^{87} \mathrm{Sr}$-izotóp fő forrása a kontinentális kéreg granitoidos összetételû kőzeteinek mállástermékét közvetítő folyóvízi beszállítás, míg a nemradiogén ${ }^{86} \mathrm{Sr}$ elsődlegesen köpenyeredetû, főleg az óceánközépi hátsági vulkanizmus révén jut a tengervízbe. Mivel a Sr biológiai izotóp-frakcionáció által nem érintett elem, így az élőlények az óceánba jutott Sr-ot a tengervíz mindenkori izotóparányának megfelelően építik be vázukba. A Sr tartózkodási ideje nagyságrendekkel nagyobb, mint az óceánok keveredési ideje, tehát Sr-ra nézve a világóceán homogén, a ${ }^{87} \mathrm{Sr} /{ }^{86} \mathrm{Sr}$ arány adott időben mindenhol azonos. A Sr ezen tulajdonságait használják fel a rétegtanban, mivel a megfelelően megőrződött kőzetből, illetve ősmaradványvázanyagból megmérhető az eredeti óceáni Sr izotópösszetétele.

Az egyes mért ${ }^{87} \mathrm{Sr} /{ }^{86} \mathrm{Sr}$ arányok azonban nem egyediek, a földtörténet során többször is előfordult ugyanaz az érték, az Sr izotóparány és az idő összefüggése nem írható le függvénykapcsolattal, vagyis pusztán ${ }^{87} \mathrm{Sr} /{ }^{86} \mathrm{Sr}$ ismeretéből a kort nem lehet egyértelmúen meghatározni. Ehhez referenciagörbe létrehozása szükséges, melyet először BURKE et al. (1982) alkottak meg. Ennek lényege, hogy független módszerekkel, kiváltképp biosztratigráfia segítségével pontosan ismert korú mintákon mérik meg a ${ }^{87} \mathrm{Sr} /{ }^{86} \mathrm{Sr}$ arányt, majd ezekhez viszonyítjuk a csak durva közelítéssel ismert korú mintákat. A földtörténetnek a neoproterozoikum második felénél fiatalabb részére mára már minden korábbinál pontosabb Sr-izotópos referenciagörbe áll rendelkezésre (MCARTHUR et al. 2012). A mérési módszerek folyamatos fejlődése és a pontosság növekedése lehetőséget nyújt a további finomításra, illetve az eddig nehezebben kezelhető minták feldolgozására is, pl. a diagenetikus felülírást figyelembe vevő modellek alapján.

A SIS egyértelmú előnye a hagyományos biosztratigráfiai módszerekkel szemben, hogy korrelálni tudja azokat a tengeri rétegsorokat is, melyek eltérő fosszíliákat tartalmaznak. A módszer korrelálni tudja azokat a rétegsorokat is, ahol korjelző ősmaradványok nem fordulnak elő. A SISval egyszerúen lehet korrelálni karbonátos és egyes nem karbonátos kőzeteket (pl. foszforitokat) is. 
Szemlénk összefoglalta a SIS alapjait és módszertanát, valamint bemutatta néhány felhasználási lehetôségét. A SIS segítségével igazolhatóak egyedi események, korolhatóak a más módszerekkel nehezen datálható karbonátplatformok, valamint endemikus faunák is, a globális korreláció lehetôségét adva. Lehetőséget nyújt például olyan problémák megoldására, mint a Paratethys regionális emeletrendszerének korrelálása a globális emeletrendszerrel, melyre már vannak törekvések (Kováč et al. 2017) és hazai kísérletek (LESS \& FRIJIA 2015), melyek egyre növekvő mérési adatbázisra alapulnak. A kormeghatározásban betöltött szerepén túl a Sr izotóprendszer sajátosságait jól ki lehet használni földtörténeti változások és folyamatok értelmezésére is. Remélhetjük, hogy a közeljövőben már Magyarországon is bevett módszerként fogják számon tartani a Sr izotópsztratigráfiát, és az mindinkább hozzájárul hazai rétegtani problémák megoldásához is.

\section{Köszönetnyilvánítás}

Köszönet illeti HAAS Jánost a kézirat korábbi változatának szakdolgozati bírálójaként tett építő kritikai megjegyzéseiért. Hálásak vagyunk John McARTHURnak a Sr izotópsztratigráfiával kapcsolatos motiváló szakmai beszélgetésekért és a referenciatáblázat (look-up table) rendelkezésre bocsátásáért, valamint Mariano PARENTE-nek a 15. Magyar Ő́slénytani Vándorgyúlésen a témában tartott inspiráló előadásáert. Natália HUDÁČKOvÁ adatok átadásával segítette munkánkat. A kézirat két bírálójának és SzTANó Orsolya fôszerkesztônek az észrevételei és javaslatai nagyot lendítettek a cikk tartalmán. A kutatást az Európai Unió és Magyarország támogatta az Európai Regionális Fejlesztési Alap társfinanszírozásában a GINOP-2.3.2.-15-2016-00009 azonosítószámú 'IKER' pályázatban. Ez a tanulmány az MTA-MTM-ELTE Paleontológiai Kutatócsoport 272. publikációja.

\section{Irodalom — References}

Alvarez, L., Alvarez, W., Asaro, F. \& Michel, H. 1980: Extraterrestrial cause for the Cretaceous-Tertiary extinction. - Science 208, 1095-1108. https://doi.org/10.1126/science.208.4448.1095

Azmy, K., Veizer, J., Wenzel, B., BASSETt, M. G. \& CoPper, P. 1999: Silurian strontium isotope stratigraphy. — Geological Society of America Bulletin 111/4, 475-483. https://doi.org/10.1130/0016-7606(1999)111<0475:ssis >2.3.co;2

Bailey, T. R., Rosenthal, Y., Mcarthur, J. M., Van De Schootbrugge, B. \& Thirlwall, M. F. 2003: Paleoceanographic changes of the Late Pliensbachian - Early Toarcian interval: a possible link to the genesis of an Oceanic Anoxic Event. — Earth and Planetary Science Letters 212/3-4, 307-320. https://doi.org/10.1016/S0012-821X(03)00278-4

BANNER, J. L. \& HANSON, G. N. 1990: Calculation of simultaneous isotopic and trace element variations during water-rock interaction with applications to carbonate diagenesis. — Geochimica et Cosmochimica Acta 54/11, 3123-3137. https://doi.org/10.1016/00167037(90)90128-8

Barbin, V., Ramseyer, K., Debenay, J. P., Schein, E., Roux, M. \& Decrouez, D. 2009: Cathodoluminescence of Recent biogenic carbonates: environmental and ontogenetic fingerprint. — Geological Magazine 128/1, 19-26. https://doi.org/10.1017/ S001675680001801X

Bernat, M., Church, T. \& Allegre, C. J. 1972: Barium and strontium concentrations in Pacific and Mediterranean sea water profiles by direct isotope dilution mass spectrometry. — Earth and Planetary Science Letters 16/1, 75-80. https://doi.org/10.1016/0012821X(72)90238-5

BRAND, U. 1987: Depositional analysis of the Breathitt Formation's marine horizons, Kentucky, U.S.A.: trace elements and stable isotopes. — Chemical Geology: Isotope Geoscience section 65/2, 117-136. https://doi.org/10.1016/0168-9622(87)90068-6

BRAND, U. 1989a: Biogeochemistry of Late Paleozoic North American brachiopods and secular variation of seawater composition. Biogeochemistry 7/3, 159-193. https://doi.org/10.1007/bf00004216

BRAND, U. 1989b: Aragonite-calcite transformation based on Pennsylvanian molluscs. — Geological Society of America Bulletin 101/3, 377390. https://doi.org/10.1130/0016-7606(1989)101<0377:actbop>2.3.co;2

Brandano, M., Cornacchia, I., RafFi, I., Tomassetti, L. \& Agostini, S. 2017: The Monterey Event within the Central Mediterranean area: The shallow-water record. — Sedimentology 64/1, 286-310. https://doi.org/10.1111/sed.12348

BRASs, G. W. 1976: The variation of the marine ${ }^{87} \mathrm{Sr} /{ }^{86} \mathrm{Sr}$ ratio during Phanerozonic time: interpretation using a flux model. Geochimica et Cosmochimica Acta 40/7, 721-730. https://doi.org/10.1016/0016-7037(76)90025-9

BRASS, G. W. \& TUREKIAN, K. K. 1974: Strontium distribution in Geosecs oceanic profiles. — Earth and Planetary Science Letters 23/1, 141-148. https://doi.org/10.1016/0012-821X(74)90041-7

Bruckschen, P., BRUhn, F., Veizer, J. \& Buhl, D. 1995: ${ }^{87} \mathrm{Sr} /{ }^{86} \mathrm{Sr}$ isotopic evolution of Lower Carboniferous seawater: Dinantian of western Europe. - Sedimentary Geology 100/1, 63-81. https://doi.org/10.1016/0037-0738(95)00103-4

BRUCKSCHEN, P., OESMANN, S. \& VEIZER, J. 1999: Isotope stratigraphy of the European Carboniferous: proxy signals for ocean chemistry, climate and tectonics. — Chemical Geology 161/1-3, 127-163. https://doi.org/10.1016/S0009-2541(99)00084-4

BrzobohatÝ, R., Kalvoda, J., FrÝda, J. \& Erban, V. 2016: Strontium isotope record of the Hygophum hygomii otoliths from the European middle Miocene. — Geobios 49/5, 349-354. https://doi.org/10.1016/j.geobios.2016.06.007

Burke, W., Denison, R., Hetherington, E., Koepnick, R., Nelson, H. \& OtTo, J. 1982: Variation of seawater ${ }^{87} \mathrm{Sr} /{ }^{86} \mathrm{Sr}$ throughout Phanerozoic time. — Geology 10/10, 516-519. https://doi.org/10.1130/0091-7613(1982)10<516:VOSSTP>2.0.CO;2 
Cleveland, W. S. 1979: Robust Locally Weighted Regression and Smoothing Scatterplots. — Journal of the American Statistical Association 74/368, 829-836. https://doi.org/10.1080/01621459.1979.10481038

CsÁszÁr, G. 1998: A rétegtan alapjai: a rétegtan és a rétegtani osztályozás. — In: BÉRCZI I. \& JÁMBor Á. (szerk.): Magyarország geológiai képzódményeinek rétegtana. MOL Rt. \& MÁFI, Budapest, 9-27.

DAs, A., Krishnaswami, S., \& KuMAR, A. 2006: Sr and ${ }^{87} \mathrm{Sr} /{ }^{86} \mathrm{Sr}$ in rivers draining the Deccan Traps (India): Implications to weathering, $\mathrm{Sr}$ fluxes, and the marine ${ }^{87} \mathrm{Sr} /{ }^{86} \mathrm{Sr}$ record around K/T. — Geochemistry, Geophysics, Geosystems 7/6, https://doi.org/10.1029/ 2005GC001081

DASCH, E. J. \& BisCAYE, P. E. 1971: Isotopic composition of strontium in Cretaceous-to-Recent, pelagic foraminifera. — Earth and Planetary Science Letters 11/1, 201-204. https://doi.org/10.1016/0012-821X(71)90164-6

Denison, R. E., Koepnick, R. B., Burke, W. H., Hetherington, E. A. \& Fletcher, A. 1994: Construction of the Mississippian, Pennsylvanian and Permian seawater ${ }^{87} \mathrm{Sr} /{ }^{86} \mathrm{Sr}$ curve. — Chemical Geology 112/1, 145-167. https://doi.org/10.1016/00092541(94)90111-2

Denison, R. E., Koepnick, R. B., Burke, W. H. \& Hetherington, E. A. 1998: Construction of the Cambrian and Ordovician seawater ${ }^{87} \mathrm{Sr} /{ }^{86} \mathrm{Sr}$ curve. - Chemical Geology 152/3-4, 325340. https://doi.org/10.1016/S0009-2541(98)00119-3

DePaolo, D. J. 1986: Detailed record of the Neogene Sr isotopic evolution of seawater from DSDP Site 590B. — Geology 14/2, 103106. https://doi.org/10.1130/0091-7613(1986)14<103:drotns>2.0.co;2

DePaolo, D. J. \& Ingram, B. L. 1985: High-Resolution Stratigraphy with Strontium Isotopes. — Science 227/4689, 938941. https://doi.org/10.1126/science.227.4689.938

Dessert, C., Dupré, B., François, L. M., Schott, J., Gaillardet, J., Chakrapani, G., \& Bajpai, S. 2001: Erosion of Deccan Traps determined by river geochemistry: impact on the global climate and the $87 \mathrm{Sr} / 86 \mathrm{Sr}$ ratio of seawater. — Earth and Planetary Science Letters 188/3-4, 459-474. https://doi.org/10.1016/S0012-821X(01)00317-X

Donnadieu, Y., Goddéris, Y., RAMStein, G., NÉdÉlec, A. \& MEert, J. 2004: A ‘snowball Earth'climate triggered by continental breakup through changes in runoff. — Nature, 428/6980, 303-306. https://doi.org/10.1038/nature02408

DudÁs, F. Ö., YuAn, D.-X., SHEN, S.-Z. \& Bowring, S. A. 2017: A conodont-based revision of the ${ }^{87} \mathrm{Sr} /{ }^{86} \mathrm{Sr}$ seawater curve across the Permian-Triassic boundary. - Palaeogeography, Palaeoclimatology, Palaeoecology 470, 40-53. https://doi.org/10.1016/ j.palaeo.2017.01.007

Elderfield, H. 1986: Strontium isotope stratigraphy. - Palaeogeography, Palaeoclimatology, Palaeoecology 57/1, 71-90. https://doi.org/10.1016/0031-0182(86)90007-6

ELDERFIELD, H. \& GIESKES, J. M. 1982: Sr isotopes in interstitial waters of marine sediments from Deep Sea Drilling Project cores. Nature 300/5892, 493-497. https://doi.org/10.1038/300493a0

ELDERFIELD, H. \& GREAVES, M. J. 1981: Strontium isotope geochemistry of Icelandic geothermal systems and implications for sea water chemistry. — Geochimica et Cosmochimica Acta 45/11, 2201-2212. https://doi.org/10.1016/0016-7037(81)90072-7

FAURE, G. \& Powell, J. L. 1972: Strontium isotope geology, 5. - Springer-Verlag Berlin Heidelberg New York. https://doi.org/ 10.1007/978-3-642-65367-4

FordinÁl, K., KRÁL, J., HARČOvÁ, E., ČECh, P., ZielinSKI, G. \& NAGY, A. $2014:{ }^{87} \mathrm{Sr} /{ }^{86} \mathrm{Sr},{ }^{13} \mathrm{C}$ a ${ }^{18} \mathrm{O}$ vo fosílnych schránkach mäkkýšov z morského, brakického a sladkovodného prostredia terciéru Západných Karpát. $\left({ }^{87} \mathrm{Sr} /{ }^{86} \mathrm{Sr},{ }^{13} \mathrm{C}\right.$ and ${ }^{18} \mathrm{O}$ in mollusc fossil shells from marine, brackish and freshwater environments from the Western Carpathians Tertiary sequences). — Mineralia Slovaca 46, $23-44$.

Frijia, G., PARente, M., Di LuCia, M. \& Mutti, M. 2015: Carbon and strontium isotope stratigraphy of the Upper Cretaceous (Cenomanian-Campanian) shallow-water carbonates of southern Italy: Chronostratigraphic calibration of larger foraminifera biostratigraphy. — Cretaceous Research 53, 110-139. https://doi.org/10.1016/j.cretres.2014.11.002

García-Ruiz, S., Moldovan, M., \& Alonso, J. I. G. 2008: Measurement of strontium isotope ratios by MC-ICP-MS after on-line Rb-Sr ion chromatography separation. — Journal of Analytical Atomic Spectrometry 23/1, 84-93. https://doi.org/10.1039/B708936H

Goddéris, Y., Donnadieu, Y., Nédélec, A., Dupré, B., Dessert, C., Grard, A., Ramstein, G. \& Francois, L. M. 2003: The Sturtian 'snowball'glaciation: fire and ice. — Earth and Planetary Science Letters 211/1-2, 1-12. https://doi.org/10.1016/S0012-821X (03)00197-3

Goldsmith, N. F., Martinell, J., Demarco, G., Bohn-Havas, M. \& DockerY, D. T. 1994: Sr-isotopic calibration of Cenozoic bivalvia and Early Miocene migrations: Eurasian carnivores to Africa (the Hazeva Formation, Israel) and African gazelles and proboscidia to Ipolytarnóc, Hungary. — Newsletters on Statigraphy 31/3, 167-183. https://doi.org/10.1127/nos/31/1994/167

Gradstein, F. M., OGG, J. G., Schmitz, M. D. \& OGG, G. M. 2012: The Geologic Time Scale 2012. Amsterdam, Elsevier, 1144 p. https://doi.org/10.1016/c2011-1-08249-8

HAAS J., ÁRKAI P., CSÁSZÁR G. \& VöRÖs A. 2008: Kőbe zárt idő — Geológiai kormeghatározás. — Magyar Tudomány 2008/11, 13001313.

Henderson, G. M., Martel, D. J., O’Nions, R. K. \& Shackleton, N. J. 1994: Evolution of seawater ${ }^{87} \mathrm{Sr} /{ }^{86} \mathrm{Sr}$ over the last $400 \mathrm{ka:}$ the absence of glacial/interglacial cycles. — Earth and Planetary Science Letters 128/3-4, 643-651. https://doi.org/10.1016/0012$821 \times(94) 90176-7$

Hess, J., Bender, M. L. \& Schilling, J.G. 1986: Evolution of the Ratio of Strontium-87 to Strontium-86 in Seawater from Cretaceous to Present. — Science 231/4741, 979-984. https://doi.org/10.1126/science.231.4741.979

Hilgen, F. J., Lourens, L. J. \& VAn Dam, J. A. 2012: The Neogene Period. — In: Gradstein, F. M., OgG, J. G., Schmitz, M. D. \& OGG, G. M. (eds): The Geologic Time Scale 2012. Elsevier, Amsterdam, pp. 923-978. https://doi.org/10.1016/b978-0-444-59425-9.00029-9

Hodell, D. A., Mueller, P. A., Mckenzie, J. A. \& Mead, G. A. 1989: Strontium isotope stratigraphy and geochemistry of the late Neogene ocean. — Earth and Planetary Science Letters 92/2, 165-178. https://doi.org/10.1016/0012-821X(89)90044-7

Hodell, D. A., Mead, G. A., \& Mueller, P. A. 1990: Variation in the strontium isotopic composition of seawater (8 Ma to present): 
Implications for chemical weathering rates and dissolved fluxes to the oceans. - Chemical Geology: Isotope Geoscience section 80/4, 291-307. https://doi.org/10.1016/0168-9622(90)90011-z

HowARTH, R. J. \& McArthuR, J. M. 1997: Statistics for Strontium Isotope Stratigraphy: A Robust LOWESS Fit to the Marine Sr-Isotope Curve for 0 to $206 \mathrm{Ma}$, with Look-up Table for Derivation of Numeric Age. — The Journal of Geology 105/4, 441-456. https://doi.org/10.1086/515938

HudáčKová, N., HalásovÁ, E., Fordinál, K., SABol, M., Joniak, P. \& KRÁL, J. 2003: Biostratigraphy and radiometric dating in the Vienna Basin Neogene (Slovak part). — Slovak Geological Magazine 9/4, 233-235.

Ingram, B. L., Coccioni, R., Montanari, A. \& Richter, F. M. 1994: Strontium Isotopic Composition of Mid-Cretaceous Seawater. Science 264/5158, 546-550. https://doi.org/10.1126/science.264.5158.546

JANZ, H. \& Vennemann, T. W. 2005: Isotopic composition (O, C, Sr, and Nd) and trace element ratios ( $\mathrm{Sr} / \mathrm{Ca}, \mathrm{Mg} / \mathrm{Ca})$ of Miocene marine and brackish ostracods from North Alpine Foreland deposits (Germany and Austria) as indicators for palaeoclimate. Palaeogeography, Palaeoclimatology, Palaeoecology 225/1, 216-247. https://doi.org/10.1016/j.palaeo.2005.06.012

JENKYNs, H. C. 2003: Evidence for rapid climate change in the Mesozoic-Palaeogene greenhouse world. — Philosophical Transactions of the Royal Society of London Series a, Mathematical Physical and Engineering Sciences 361/1810, 1885-1916. https://doi.org/ 10.1098/rsta.2003.1240

JENKYNS, H. C. 2010: Geochemistry of oceanic anoxic events. — Geochemistry, Geophysics, Geosystems 11/3, Q03004. https://doi.org/ $10.1029 / 2009$ GC002788

Jones, C. E., Jenkyns, H. C. \& Hesselbo, S. P. 1994a: Strontium isotopes in Early Jurassic seawater. — Geochimica et Cosmochimica Acta 58/4, 1285-1301. https://doi.org/10.1016/0016-7037(94)90382-4

Jones, C. E., Jenkyns, H. C., Coe, A. L. \& Stephen, H. P. 1994b: Strontium isotopic variations in Jurassic and Cretaceous seawater. — Geochimica et Cosmochimica Acta 58/14, 3061-3074. https://doi.org/10.1016/0016-7037(94)90179-1

Kaufman, A. J., Jacobsen, S. B. \& Knoll, A. H. 1993: The Vendian record of Sr and C isotopic variations in seawater: Implications for tectonics and paleoclimate. — Earth and Planetary Science Letters 120/3, 409-430. https://doi.org/10.1016/0012-821X(93)90254-7

Kocsis L. 2016: Újabb eredmények az ipolytarnóci cápafogas rétegről, illetve annak faunájáról. — In: GuBA S. \& SzARVAS I. (szerk.): Ósmaradványok nyomában : Ipolytarnóc földtani megismerése I. Bükki Nemzeti Park Igazgatóság, Eger, 53-76.

Kocsis, L. S., Vennemann, T. W. \& Fontignie, D. 2007: Migration of sharks into freshwater systems during the Miocene and implications for Alpine paleoelevation. — Geology 35/5, 451-454. https://doi.org/10.1130/G23404A.1

Kocsis, L., Vennemann, T. W., Hegner, E., Fontignie, D. \& TutKen, T. 2009: Constraints on Miocene oceanography and climate in the Western and Central Paratethys: O-, Sr-, and Nd-isotope compositions of marine fish and mammal remains. - Palaeogeography, Palaeoclimatology, Palaeoecology 271/1-2, 117-129. https://doi.org/10.1016/j.palaeo.2008.10.003

Kocsis, L., Dulai, A., Bitner, M. A., Vennemann, T. \& Cooper, M. 2012: Geochemical compositions of Neogene phosphatic brachiopods: Implications for ancient environmental and marine conditions. - Palaeogeography, Palaeoclimatology, Palaeoecology 326328, 66-77. https://doi.org/10.1016/j.palaeo.2012.02.004

Korte, C., Kozur, H. W., Bruckschen, P. \& Veizer, J. 2003: Strontium isotope evolution of Late Permian and Triassic seawater. — Geochimica et Cosmochimica Acta 67/1, p. 4762. https://doi.org/10.1016/S0016-7037(02)01035-9

Kováč, M., HudáčKová, N., Halásová, E., Kováčová, M., Holcová, K., OszczypKo-Clowes, M., Báldi, K., Less, G., Nagymarosy, A. \& Ruman, A. 2017: The Central Paratethys palaeoceanography: a water circulation model based on microfossil proxies, climate, and changes of depositional environment. - Acta Geologica Slovaca 9/2, 75-114.

Kováč, M., Halásová, E., HudáčKová, N., Holcová, K., HyžnÝ, M., Jamrich, M. \& Ruman, A. 2018: Towards better correlation of the Central Paratethys regional time scale with the standard geological time scale of the Miocene Epoch. _ Geologica Carpathica 69/3, 283-300. https://doi.org/10.1515/geoca-2018-0017

KÜRSCHNER, W., BECKer, R. T., BuhL, D. \& VeIZER, J. 1993: Strontium isotopes in conodonts: Devonian-Carboniferous transition, the northern Rhenish Slate Mountains, Germany. — Annales de la Société géologique de Belgique 115/2, 595-621.

Less G. \& FriJiA, G. 2015: Új Sr-izotóp koradatok a középső-Paratethysből. — In: Bosnakoff M. \& Dulai A. (szerk.): 18. Magyar Óslénytani Vándorgyúlés Varbó-Fónagyság. Magyarhoni Földtani Társulat.

Less, Gy., Benedetti, A., Cahuzac, B., Parente, M,. Pignatti, J. \& Torres-Silva, A. 2015a: Supposed trans-Atlantic migration of Heterostegina around the Eocene/Oligocene boundary. — Berichte des Institutes für Erdwissenschaften Karl-Franzens-Universität Graz 21, p. 222.

Less, Gy., FriJia, G., Filipescu, S., Holcová, K., Mandic, O. \& Sztanó, O. 2015b: New Sr-isotope stratigraphy (SIS) age-data from the Central Paratethys. - Berichte des Institutes für Erdwissenschaften Karl-Franzens-Universität Graz 21, p. 223,

Ludwig, K. R., Halley, R. B., Simmons, K. R. \& Peterman, Z. E. 1988: Strontium-isotope stratigraphy of Enewetak Atoll. — Geology $16 / 2,173-177$.

MacLeod, K. G., Huber, B. T. \& FullagaR, P. D. 2001: Evidence for a small ( 0.000 030) but resolvable increase in seawater ${ }^{87} \mathrm{Sr} /{ }^{86} \mathrm{Sr}$ ratios across the Cretaceous-Tertiary boundary. — Geology 29/4, 303-306. https://doi.org/10.1130/0091-7613(1988)016<0173: sisoea>2.3.co;2

Martin, E. E. \& MacDougall, J. D. 1991: Seawater Sr isotopes at the Cretaceous/Tertiary boundary. — Earth and Planetary Science Letters 104/2, 166-180. https://doi.org/10.1016/0012-821X(91)90202-S

MCARthur, J. M. 1994: Recent trends in strontium isotope stratigraphy. — Terra Nova 6/4, 331-358. https://doi.org/10.1111/j.13653121.1994.tb00507.x

McArthur, J. M., Sahami, A. R., Thirlwall, M., Hamilton, P. J. \& Osborn, A. O. 1990: Dating phosphogenesis with strontium isotopes. — Geochimica et Cosmochimica Acta 54/5, 1343-1351. https://doi.org/10.1016/0016-7037(90)90159-I

McArthur, J. M., Kennedy, W. J., Chen, M., Thirlwall, M. F. \& Gale, A. S. 1994: Strontium isotope stratigraphy for Late Cretaceous 
time: Direct numerical calibration of the Sr isotope curve based on the US Western Interior. - Palaeogeography, Palaeoclimatology, Palaeoecology 108/1, 95-119. https://doi.org/10.1016/0031-0182(94)90024-8

McArthur, J. M., Thirlwall, M. F., Engkilde, M., Zinsmeister, W. J. \& Howarth, R. J. 1998: Strontium isotope profiles across K/T boundary sequences in Denmark and Antarctica. — Earth and Planetary Science Letters 160/1, 179-192. https://doi.org/ $10.1016 / \mathrm{S} 0012-821 \mathrm{X}(98) 00058-2$

McArthur, J. M., Donovan, D. T., Thirlwall, M. F., Fouke, B. W. \& Mattey, D. 2000: Strontium isotope profile of the early Toarcian (Jurassic) oceanic anoxic event, the duration of ammonite biozones, and belemnite palaeotemperatures. — Earth and Planetary Science Letters 179/2, 269-285. https://doi.org/10.1016/S0012-821X(00)00111-4

McArthur, J. M., Howarth, R. J. \& Bailey, T. R. 2001: Strontium Isotope Stratigraphy: LOWESS Version 3: Best Fit to the Marine SrIsotope Curve for 0-509 Ma and Accompanying Look-up Table for Deriving Numerical Age. — The Journal of Geology 109/2, 155170. https://doi.org/10.1086/319243

McArthur, J. M., Howarth, R. J. \& Shields, G. A. 2012: Strontium Isotope Stratigraphy. — In: Gradstein, F. M., OGG, J. G., Schmitz, M. D. \& OGG, G. M. (eds): The Geologic Time Scale. Elsevier, Boston, 127-144. https://doi.org/10.1016/B978-0-444-594259.00007-X

McArthur, J. M., Steuber, T., Page, K. N. \& Landman, N. H. 2016: Sr-Isotope Stratigraphy: Assigning Time in the Campanian, Pliensbachian, Toarcian, and Valanginian. — The Journal of Geology 124/5, 569-586. https://doi.org/10.1086/687395

Miall, A. D. 2013: Sophisticated stratigraphy. — Geological Society of America Special Papers 500, 169-190. https://doi.org/10.1130/ 2013.2500(05)

Miller, E. K., Blum, J. D. \& Friedland, A. J. 1993: Determination of soil exchangeable-cation loss and weathering rates using Sr isotopes. - Nature 362/6419, 438-441 https://doi.org/10.1038/362438a0

Miller, K. G., Feigenson, M. D., Kent, D. V. \& Olsson, R. K. 1988: Upper Eocene to Oligocene isotope $\left({ }^{87} \mathrm{Sr} /{ }^{86} \mathrm{Sr},{ }^{18} \mathrm{O},{ }^{13} \mathrm{C}\right) \mathrm{standard}$ section, Deep Sea Drilling Project Site 522. — Paleoceanography 3/2, 223-233. https://doi.org/10.1029/PA003i002p00223

Morrison, J. O. \& BRAND, U. 1988: An evaluation of diagenesis and chemostratigraphy of upper cretaceous molluscs from the Canadian Interior Seaway. — Chemical Geology: Isotope Geoscience section 72/3, 235-248. https://doi.org/10.1016/0168-9622(88)90027-9

Müller, T., Price, G. D., Bajnai, D., Nyerges, A., Kesjár, D., Raucsik, B., Varga, A., Judik, K., Fekete, J., May, Z. \& PÁlfy, J. 2017 : New multiproxy record of the Jenkyns Event (also known as the Toarcian Oceanic Anoxic Event) from the Mecsek Mountains (Hungary): Differences, duration and drivers. - Sedimentology 64/1, 66-86. https://doi.org/10.1111/sed.12332

Oslick, J. S., Miller, K. G., Feigenson, M. D. \& Wright, J. D. 1994: Oligocene Miocene strontium isotopes: Stratigraphic revisions and correlations to an inferred glacioeustatic record. — Paleoceanography 9/3, 427-443. https://doi.org/10.1029/94pa00249

Palmer, M. R. \& Elderfield, H. 1985: Sr isotope composition of sea water over the past 75 Myr. - Nature 314/6011, 526528.https://doi.org/10.1038/314526a0

Parente, M., HaAs, J., FriJia, G. \& Less, Gy. 2013: First data on the strontium isotope stratigraphy of the Upper Cretaceous rudist limestones of Hungary, the Ugod Limestone Formation. - Abstract Book, $9^{\text {th }}$ International Symposium on the Cretaceous System, 101.

Pearce, C. R., Parkinson, I. J., Gaillardet, J., Charlier, B. L. A., Mokadem, F. \& Burton, K. W. 2015: Reassessing the stable ( ${ }^{88 / 86}$ Sr) and radiogenic $\left({ }^{87} \mathrm{Sr} /{ }^{86} \mathrm{Sr}\right)$ strontium isotopic composition of marine inputs. - Geochimica et Cosmochimica Acta 157, $125-146$. https://doi.org/10.1016/j.gca.2015.02.029

Peterman, Z. E., Hedge, C. E. \& Tourtelot, H. A. 1970: Isotopic composition of strontium in sea water throughout Phanerozoic time. — Geochimica et Cosmochimica Acta 34/1, 105-120. https://doi.org/10.1016/0016-7037(70)90154-7

Piller, W. E., Harzhauser, M. \& Mandic, O. 2007: Miocene Central Paratethys stratigraphy — current status and future directions. Stratigraphy 4/2-3, 151-168.

Pippèrr, M., Reichenbacher, B., Witt, W. \& Rocholl, A. 2007: The Middle and Upper Ottnangian of the Simssee area (SE Germany): Micropalaeontology, biostratigraphy and chronostratigraphy. - Neues Jahrbuch für Geologie und Paläontologie, Abhandlungen 245, 353-378. https://doi.org/10.1127/0077-7749/2007/0245-0353

Popp, B. N., ANDERSON, T. F. \& SANDBERG, P. A. 1986: Brachiopods as indicators of original isotopic compositions in some Paleozoic limestones. — Geological Society of America Bulletin 97/10, 1262-1269. https://doi.org/10.1130/0016-7606(1986)97<1262:baiooi>2.0.co;2

Price, G. D., FôzY, I. \& PÁlfy, J. 2016: Carbon cycle history through the Jurassic-Cretaceous boundary: A new global ${ }^{13} \mathrm{C}$ stack. Palaeogeography, Palaeoclimatology, Palaeoecology 451, 46-61. https://doi.org/10.1016/j.palaeo.2016.03.016

RavizZA, G. E., \& Zachos, J. C. 2003: Records of Cenozoic ocean chemistry. — Treatise on geochemistry 6, 625. https://doi.org/ 10.1016/b0-08-043751-6/06121-1

Raymo, M. E., \& Ruddiman, W. F. 1992: Tectonic forcing of late Cenozoic climate. — Nature 359(6391), 117-122. https://doi.org/ $10.1038 / 359117 \mathrm{a} 0$

RichteR, F. M. \& LiAng, Y. 1993: The rate and consequences of Sr diagenesis in deep-sea carbonates. — Earth and Planetary Science Letters 117/3, 553-565. https://doi.org/10.1016/0012-821X(93)90102-F

Richter, F. M. \& TUREKIAN, K. K. 1993: Simple models for the geochemical response of the ocean to climatic and tectonic forcing. Earth and Planetary Science Letters 119/1, 121-131. https://doi.org/10.1016/0012-821X(93)90010-7

Roveri, M., Lugli, S., MAnzi, V., Gennari, R. \& Schreiber, B. C. 2014: High-resolution strontium isotope stratigraphy of the Messinian deep Mediterranean basins: Implications for marginal to central basins correlation. — Marine Geology 349, 113-125. https://doi.org/ 10.1016/j.margeo.2014.01.002

Ruhl, M., Hesselbo, S. P., Hinnov, L., Jenkyns, H. C., Xu, W., Riding, J. B., Storm, M., Minisini, D., Ullmann, C. V. \& Leng, M. J. 2016: Astronomical constraints on the duration of the Early Jurassic Pliensbachian Stage and global climatic fluctuations. — Earth and Planetary Science Letters 455, 149-165. https://doi.org/10.1016/j.eps1.2016.08.038 
Sant, K., V. Palcu, D., Mandic, O. \& Krijgsman, W. 2017: Changing seas in the Early-Middle Miocene of Central Europe: a Mediterranean approach to Paratethyan stratigraphy. — Terra Nova 29/5, 273-281. https://doi.org/ 10.1111/ter.12273

SaWaki, Y., Kawai, T., Shibuya, T., Tahata, M., Omori, S., Komiya, T., Yoshida, N., Hirata, T., Ohno, T., Windley, B. F. \& Maruyama, S. 2010: ${ }^{87} \mathrm{Sr} /{ }^{86} \mathrm{Sr}$ chemostratigraphy of Neoproterozoic Dalradian carbonates below the Port Askaig Glaciogenic Formation, Scotland. - Precambrian Research 179/1-4, 150-164. https://doi.org/10.1016/j.precamres.2010.02.021

SCHLANGER, S. O. \& JENKYNS, H. C. 1976: Cretaceous oceanic anoxic events: Causes and consequences. — Geologie en Mijnbouw 55, 179-184.

Spooner, E. T. C., Beckinsale, R. D., Fyfe, W. S. \& SMewing, J. D. 1974: ${ }^{18}$ O enriched ophiolitic metabasic rocks from E. Liguria (Italy), Pindos (Greece), and Troodos (Cyprus). — Contributions to Mineralogy and Petrology 47/1, 41-62. https://doi.org/10.1007/ bf00418556

Steuber, T., Korbar, T., Jelaska, V. \& Gušić, I. 2005: Strontium-isotope stratigraphy of Upper Cretaceous platform carbonates of the island of Brač (Adriatic Sea, Croatia): implications for global correlation of platform evolution and biostratigraphy. — Cretaceous Research 26/5, 741-756. https://doi.org/10.1016/j.cretres.2005.04.004

TAYLOR, S. R. 1965: The application of trace element data to problems in petrology. — Physics and Chemistry of the Earth 6, $133-213$. https://doi.org/10.1016/0079-1946(65)90014-5

Teschner, C. \& Reichenbacher, B. 2017: Otolith-based age determination of mid-Burdigalian marine sediments in the North Alpine Foreland Basin. — Bulletin of Geosciences 92/2, 143-152. https://doi.org/10.3140/bull.geosci.1659

ThiRLwall, M. F. 1991: Long-term reproducibility of multicollector $\mathrm{Sr}$ and $\mathrm{Nd}$ isotope ratio analysis. - Chemical Geology: Isotope Geoscience section 94/2, 85-104. https://doi.org/10.1016/0168-9622(91)90002-E

VEIZER, J. 1989: Strontium isotopes in seawater through time. - Annual Review of Earth and Planetary Sciences 17/1, 141-167. https://doi.org/10.1146/annurev.ea.17.050189.001041

VeIzeR, J. \& COMPSTON, W. 1974: ${ }^{87} \mathrm{Sr} /{ }^{86} \mathrm{Sr}$ composition of seawater during the Phanerozoic. — Geochimica et Cosmochimica Acta 38/9, 1461-1484. https://doi.org/10.1016/0016-7037(74)90099-4

VeIZER, J. \& COMPSTON, W. 1976: ${ }^{87} \mathrm{Sr} /{ }^{86} \mathrm{Sr}$ in Precambrian carbonates as an index of crustal evolution. — Geochimica et Cosmochimica Acta 40/8, 905-914. https://doi.org/10.1016/0016-7037(76)90139-3

VEIZER, J. \& FRITZ, P. 1976: Possible control of post-depositional alteration in oxygen paleotemperature determinations. — Earth and Planetary Science Letters 33/2, 255-260. https://doi.org/10.1016/0012-821X(76)90232-6

Veizer, J., Compston, W., Hoefs, J. \& Nielsen, H. 1982: Mantle buffering of the early oceans. — Naturwissenschaften 69/4, 173-180. https://doi.org/10.1007/bf00364890

Veizer, J., Compston, W., Clauer, N. \& Schidlowski, M. 1983: ${ }^{87} \mathrm{Sr} /{ }^{86} \mathrm{Sr}$ in Late Proterozoic carbonates: evidence for a "mantle" event at 900 Ma ago. — Geochimica et Cosmochimica Acta 47/2, 295-302. https://doi.org/10.1016/0016-7037(83)90142-4

Veizer, J., Buhl, D., Diener, A., Ebneth, S., Podlaha, O. G., Bruckschen, P., Jasper, T., Korbe, C., SchaAf, M., Ala, D. \& Army, K. 1997: Strontium isotope stratigraphy: potential resolution and event correlation. - Palaeogeography, Palaeoclimatology, Palaeoecology 132, 65-77. https://doi.org/10.1016/S0031-0182(97)00054-0

Veizer, J., Ala, D., Azmy, K., Bruckschen, P., Buhl, D., Bruhn, F., Carden, G. A. F., Diener, A., Ebneth, S., Godderis, Y., Jasper, T., Korte, C., Pawellek, F., Podlaha, O. G. \& Strauss, H. 1999: ${ }^{87} \mathrm{Sr} /{ }^{86} \mathrm{Sr},{ }^{13} \mathrm{C}$ and ${ }^{18} \mathrm{O}$ evolution of Phanerozoic seawater. - Chemical Geology 161/1-3, 59-88. https://doi.org/10.1016/S0009-2541(99)00081-9

VenNemAnN, T. W. \& Hegner, E. 1998: Oxygen, strontium, and neodymium isotope composition of fossil shark teeth as a proxy for the palaeoceanography and palaeoclimatology of the Miocene northern Alpine Paratethys. — Palaeogeography, Palaeoclimatology, Palaeoecology 142/3, 107-121. https://doi.org/10.1016/S0031-0182(98)00062-5

VonHOF, H. B., \& SMIT, J. 1997: High-resolution late Maastrichtian - early Danian oceanic 87Sr/86Sr record: Implications for CretaceousTertiary boundary events. — Geology 25/4, 347-350. https://doi.org/10.1130/0091-7613(1997)025<0347:hrlmed>2.3.co;2

Vonhof, H. B., Jagt, J. W. M., Immenhauser, A., Smit, J., Van Den Berg, Y. W., Saher, M., Keutgen, N. \& Reijmer, J. J. G. 2011: Belemnite-based strontium, carbon and oxygen isotope stratigraphy of the type area of the Maastrichtian Stage. — Netherlands Journal of Geosciences — Geologie en Mijnbouw 90/2-3, 259-270. https://doi.org/10.1017/S0016774600001141

Wickman, F. E. 1948: Isotope Ratios: A Clue to the Age of Certain Marine Sediments. - The Journal of Geology 56/1, 61-66. https://doi.org/10.1086/625478

Wolery, T. J. \& SLEEP, N. H. 1976: Hydrothermal Circulation and Geochemical Flux at Mid-Ocean Ridges. — The Journal of Geology 84/3, 249-275. https://doi.org/10.1086/628195

Zachos, J., Pagani, M., Sloan, L., Thomas, E. \& Billups, K. 2001: Trends, Rhythms, and Aberrations in Global Climate 65 Ma to Present. — Science 292/5517, 686-693. https://doi.org/10.1126/science.1059412

Kézirat beérkezett: 2018. 09. 14. 